\title{
THE LEGACY OF WILLIAM BELL MALLOCH, M.D.: THE MCGILL, MOOSE FACTORY AND MCCORD CONNECTION
}

\section{By Cath Oberholtzer}

In 1870, McGill graduate Dr. William Bell Malloch responded to an urgent request for a Medical Officer to serve at Moose Factory. Travelling the last five hundred miles on snow shoes through severe winter conditions, Malloch demonstrated a tenacity, which stood him in good stead for living in the North. His eight years at this remote post allow us to gain an insight into a period seldom covered in fur trade history and an important chapter in Canadian history. Of great importance to a number of research areas, the respect for Malloch and his young family is reflected by the quality of the artifacts given to them by the Cree. Now in the McCord Museum of Canadian History, these objects, along with photographs, archival material, and a few of Malloch's personal possessions, form an invaluable collection of Cree material culture and a native perspective of their past. As such, the collection stands as concrete evidence connecting McGill University, Moose Factory and the McCord Museum.

Le docteur William Bell Malloch, diplômé de McGill, acceptait en 1870 de se rendre à Moose Factory pour combler le poste de médecin du village. Parcourant les derniers 500 milles en raquette, le Dr. Malloch à vite démontré sa ténacité et ses aptitudes pour survivre au rudes conditions du Grand Nord. Ses huit années dans ce village isolé nous offrent aujourd'hui une perspective sur une période mal connue de la traite des fourrures qui présente un chapitre important de l'histoire du Canada. Le nombre et la qualité des artéfacts offerts par les Cris démontrent le respect des autochtones pour le Dr. Malloch et sa jeune famille. L'ensemble des artéfacts cris, auxquels s'ajoutent des photos, des archives et des articles personnels du Dr. Malloch, forment une impressionnante collection à caractère culturel et historique, déposée au Musée McCord d'histoire canadienne. Cette collection, d'une grande importance pour plusieurs domaines de recherche, démontre le lien étroit qui unit l'université McGill, Moose Factory et le Musée McCord.

I N 1935, THE MCCORD MUSEUM of Canadian History received a small, well-provenanced collection donated by its owner. This collection, comprised of native and non-native ethnographic items, textual documents, and archival photographs, yields valuable historical glimpses of nineteenth century Euro-Canadian society, a relatively unknown decade of life at Moose Factory, and the nexus of native and non-native cultures during that period. Supported by archival records and illus-

trated by both studio and amateur photographs, this definitively dated collection possesses great significance for numerous areas of enquiry. For a researcher interested in Cree ethnology and material culture, the importance of this collection cannot be surpassed. Not only does it provide tangible evidence of the technical expertise, aesthetics and material culture of the Cree in this James Bay community, it also serves as a much-needed comparative source for Cree items lacking dates and community origins. 
Acquired by William Bell Malloch, physician for the Hudson's Bay Company (hereafter HBC) at Moose Factory from 1870 to 1878 , the ethnographic component of the collection comprises a child's outfit, pairs of moccasins, a model tikanagan (cradle board), a model paddle and miscellaneous items all meticulously handcrafted by the Cree (see Appendix I and Figs. 7-14). Complementing these are several items used or created by Malloch which allow us to gain a wider perspective of life in the North. The skill exhibited in the sewing, embroidery and beading of the Cree items is superlative, the preparation of the indigenous materials expertly done, and the attention to detail impressive. Furthermore, certain construction and stitchery details indicate that the woman - or women - who made these items also possessed precise knowledge of European dressmaking techniques. ${ }^{1}$ The tiny tikanagan, made to hold its owner's "baby" doll, is as exact as one made for a much-loved infant. Indisputable provenance is validated through the studio portrait of. Malloch's three-year-old daughter, Alice, who was photographed wearing these very same items with the tiny tikanagan at her feet (Fig. 1). Corresponding portraits of Dr. Malloch (Fig. 2) and his son, Stewart (Fig. 3), illustrate other Cree-made items which are not included in the McCord collection.
Who was this William Bell Malloch, M.D., C.M. who had walked 500 miles on snow shoes to take up his position at Moose Factory, who was deeply involved in all aspects of life at the trading posts, and who shared numerous interests such as a pioneering amateur photographer with post personnel, yet received so little mention in the Hudson Bay Company records of Moose Factory? Certainly this small collection, donated by his daughter Alice, and now housed in the McCord Museum, sheds light on the man who obviously had engendered profound respect and affection at this northerly post.

\section{WILLIAM BELL MALLOCH}

William Bell Malloch, born March 1, 1845, was a member of two of the most prominent families in Perth, Ontario, considered the capital ${ }^{2}$ of the heavily Scots-colonized areas of eastern Ontario. His maternal grandfather, the classically-educated Reverend William Bell, M.A. was a respected clergyman, educator and a devoted promoter of further Scottish immigration to Canada West, but who was also renowned as a self-proclaimed fighting minister often settling an issue with his fists. ${ }^{3}$ Representing the judicial side of the community, Malloch's father, Scottish-born John Glass Malloch, was a lawyer who

1 Carol Judd speculates that the chief officers at Moose Factory probably lived with their native wives within the confines of the post almost from the beginning. From this we can extrapolate that from 1730 (and earlier at older posts) a certain group of native women learned about European ways. Carol Judd, "Housing the Homeguard at Moose Factory: 1730-1982," The Canadian Journol of Native Studies 3, no. 1 (1983): 23-37.

2 As noted by the Rev. William Bell in his treatise Hints to Emigrants, in a Series of Letters from Upper Canada (Edinburgh: Printed for Waugh and Innes, 1824).

3 William Bell, Diary, vol. V, p. 74, Queen's University Archives \#2402.

4 William Bell, Diary, vol. X, p. 63, Queen's University Archives \#2402.

5 George Malloch, a paternal uncle, was a judge of the United Counties of Leeds and Grenville, another uncle, Edward Malloch, was a member of the Provincial Parliament, and cousin Archibald Malloch graduated from McGill as a physician in 1878. Two of Bell's sons, Ebenezer and Robert were, respectively, a lawyer and an elected government representative. (William Bell, Diary, vol. XVI, p. 13, Queen's University Archives \#2402).

6 Wiliam Bell, Diary, vol. XV, p.30, Queen's University Archives \#2402.

7 William Bell, Diary, vol. XV, p. 107, Queen's University Archives \#2402.

8 lbid., 152. 
"had succeeded beyond expectation." The August 1835 marriage of Bell's daughter, Isabella, to John Malloch, united these two leading families ${ }^{5}$ each governed by strong Presbyterian principles, close family ties, and coloured by Scottish highlander blood.

Less than two years after his birth, Malloch's mother died, leaving his father with five young children to raise. His father married again in 1848 to Mary Stewart, who died in 1851 leaving another child. His third and last marriage was to Margaret Gillies Wylie, who would survive her husband by twenty years. While William may have been too young to remember his mother's funeral - "the largest ever seen in Perth" - and his father's remarriages, we can only imagine how wide his eyes, as a fiveyear old, must have opened in wonderment when von Amberg's collection of elephants and other wild beasts visited Perth in July of $1850 .^{7}$ At age seven, excitement prevailed when one thousand people participated in celebrating the twentieth anniversary of the Sons of Temperance, complete with a new brass band which performed in "Malloch's grove." 8 This is all we know about William's formative years other than what can be surmised of early years spent in a small ${ }^{9}$ community surrounded by a large and loving family. And, probably, like most mid-nineteenth century boys, simple pleasures filled his days and prepared him for his later sojourn in the north: boating, cricket, quoits, swimming, fishing, and shooting during summer days; while in winter activities included shinny, skating, coasting and snow shoeing. ${ }^{10} \mathrm{He}$ was certainly old enough on 26 May 1854 to appreciate the chilling drama of the complete eclipse of the sun. ${ }^{11}$ By 1858 , when young William was thirteen, his father's stature as an influential and respected Judge became manifested in a newly-built seventeen-room mansion, "Victoria Hall," considered one of the finest private residences in eastern Canada West. ${ }^{12}$ Indeed, this grand mansion became the favoured venue for lively family dinners complete with aunts, uncles and cousins, ${ }^{13}$ and attests to a way of life followed by the privileged class. The Malloch family would have been among the crowd of excited Perth citizens gathered on a bitterly cold February day in 1859 to witness the arrival of the first railway train from Brockville, marking the strong ties between these two communities. ${ }^{14}$ And quite possibly, William took part in, or at least observed, Perth's first regatta held in the summer of 1863

Malloch's attendance at McGill's Medical School presupposes that he had completed a secondary education, a luxury available only to the sons of wealthy families of that period. ${ }^{15}$ According to McGill Records, ${ }^{16}$ he registered in 1863 as a student in the Faculty of Medicine under the patronage of kinsman, Dr. James Alexander Grant, ${ }^{17}$ and signed the Gradu-

9 The population of Perth in 1851 was 1916. By 1871, after Malloch had left for the north, the population was 2375 (Edward Shortt, ed. Perth Remembered (Perth, Ont.: Mortimer, 1967), 159.

10 Shortt, Perth Remembered, 71.

11 William Bell, Diary, vol. XVI, p.7, Queen's University Archives \#2402.

12 Howard Morton Brown, Lanark Legacy: Nineteenth Century Climpses of an Ontario County (Perth: The Corporation of the County of Lanark, 1984): 75; Shortt, Perth Remembered, 84; Larry Turner, Perth: Tradition and Style in Eastern Ontario (Toronto: Natural Heritage/ Natural History Inc. 1992), 76

13 These family occasions may well have included first cousins Robert Bell who later becarne renowned as a geographer, and a physician in the Canadian north, Maria Malloch (second daughter of Edward Malloch, M.P.P.) who later became the wife of Malloch's sponsor, Sir James Grant, and Mary Stewart Malloch who became Malloch's wife. (William Bell, Diary, vols. III-XVI, Queen's University Archives \#2402)

14 Shortt, Perth Remembered, 80 .

15 Ibid., 71.

16 Letter from the Assistant University Archivist to Stanley Triggs, 9 December 1970, Notman Archives, McCord Museum. 
ates' Register in 1867. However, Malloch's activities while attending McGill, and for the period between graduation and his acceptance of the position with. the $\mathrm{HBC}$ are unknown.

\section{CALL TO THE NORTH}

Malloch's position with the HBC was initiated by a letter dated 20 September 1869 sent by Chief Factor James Anderson to the Company's Secretary in London requesting a medical doctor for the Moose Factory post. ${ }^{18}$ The previous doctor, sent out from England in 1869, had proven unsuitable and had returned by the same Company vessel in September of that year. As a consequence of this urgent request for a replacement having been forwarded to Montreal, ${ }^{19}$ Chief Factor Dugald Mactavish wrote from Montreal on January 4, 1870 to instruct Dr. William Bell Malloch at Sand Point (Ottawa) of the procedures and route he was to undertake from Ottawa to Moose Factory, ${ }^{20}$ Malloch, having telegraphed his acceptance $^{21}$ to sign-on for three years as Surgeon $\&$ Clerk at $£ 120$ per annum, ${ }^{22}$ left early on the morning of January $7,1870^{23}$ to begin his arduous journey from Ottawa northward to the Post ${ }^{24}$ (Fig. 4). His first letters home recount a lively chronicle of this trip and provide our first glimpses of the northern "metropolis of this vast wooded country." 25

Travelling by stage coach, Malloch left Ottawa behind and went as far as Mattawa before it was neces sary to strap on snow shoes for the remainder of the trip. Travelling from Mattawa with Thomas, a halfbreed $^{26}$ cook and servant, two Indian guides and packeteers by the names of Jean Baptiste and Cannanassay, and his faithful dog, Busco, they followed the same route the canoes took in the summer. Details of Malloch's tale begin only after leaving Abitibi behind on their trek further north. Writing from his final destination at Moose Factory, he relates how heavy snow, extreme cold, and the need for a replacement guide slowed progress and severely diminished their provisions. According to Malloch, the cold was so intense that, "If we put down our tin basin of boiling tea for a moment it was frozen into solid ice. Between every bite I had to put my fork in the fire, as it would stick to my mouth... We dared not sleep as we knew it would have been the sleep of death." 27

17 Dr. James Alexander Grant (later Sir James), himself a graduate of McGill's Faculty of Medicine, married Maria, second daughter of Edward Malloch, M.P.P. in January of 1856. (Henry James Morgan, The Canadian Men and Women of the Time: A Handbook of Canadian Biography of Living Characters (Toronto: William Briggs, 1912): 468. Crant's sponsoring of his wife's first cousin was an accepted - and indeed, expected - behaviour at that time.

18 Hudson's Bay Company Archives (HBCA), Correspondence, A.11/46, fo.668-9. Prior to 1905 when the Canadian government made medical services available to indigenous populations within reach of transportation, medical care fell to the HBC (Percy $E$. Moore, "Health for Indians and Eskimos," Canadian Geographical journal 48, no.6 (1954): 216-21. See also, Jennifer Blythe, Peggy Martin Brizinski, and Sarah Preston, "I Was Never Idle": Women and Work in Moosonee and Moose Factory, TASO Report No.21, (Hamilton, Ont.: McMaster University, 1985): 31. Certainly the missionaries also supplied medical care. Prior to Malloch's arrival Rev. John Horden, writing on January 24, 1868 to Rev. J. Mee, the Lay Secretary of the Church Missionary Society, bemoaned that "In addition to this [his religious and educational duties] I have likewise the duties of "doctor" to attend to there being no medical man here this winter, and we have had a great deal of sickness..." (Church Missionary Society, Mg 17, vol.B2; Reel A-80 1868-1878, p.22; microfilm).

19 Hudson's Bay Company Archives, Correspondence, A. 6/43, fo.162.

20 HBCA, Correspondence, B.134/b/29, fo.745

21 Ibid.

22 HBCA, Correspondence, A.6/43, fo. 190.

23 HBCA, Correspondence, B.134/C/117, fo. 22 .

24 There is no information indicating why Malloch chose to take this northern posting. However, given the strong ties with family in Brockville, one of the retirement capitals for Hudson Bay Company personnel, and with relatives in Hamilton, another favoured 
Undaunted, they persevered, slowed only by the unmitigated pain of mal de raquette. ${ }^{28}$ Their depleted rations, however, reached the point when the men had to steep the flour bag, turn it inside out to scrape off any edible flour adhering to the cloth, and then drink this broth. When some "squaws" brought Malloch boiled fish roe in a dirty tin dish, he ate it with a dirty iron spoon, assuring his readers that he "never enjoyed anything more in my life." A chance encounter with Indian hunters provided a welcome supply of frozen moose meat, and like starving men in similar situations, they gorged themselves until they became sick. The cold continued, and on the last stretch into Moose Factory biting winds froze Malloch's nose, cheek and one ear solid. And Busco, now so thin that his bones were "almost sticking through his skin," had to be revived at one point with a piece of venison doused with the last of Malloch's brandy. Together they reached Moose Factory on the 19th of February 1870. This tenacity exhibited by Malloch - and by his canine companion - were indicative of the inherent strengths of character and physical endurance which were to be called upon during his tenure at Moose Factory. ${ }^{29}$

\section{MOOSE FACTORY: METROPOLIS OF THE NORTH}

After 22 days on snow shoes through the cold, Malloch's first impression of Moose Factory (Fig. 4) had a lasting impact: "Every man, woman and child at Moose factory [sic] came out to have a look at the new-comer, and soon made me forget my late sufferings from, cold, hunger and fatigue." ${ }^{30}$ His initial response was to write a detailed description of "Hazy Island," his new home. ${ }^{31}$ Thus from his early letters of 1870 , we are given glimpses of Moose Factory, often providing details which $\mathrm{HBC}$ and missionary reports lack or which remain buried in obscurity. For example, just after his arrival Malloch wrote rathet cryptically:

The population of Moose in the winter is about 150 , and from 300 to 400 in summer. The company employs about 60 servants... They keep about 70 head of cattle here. There is a nice little church which boasts of a harmonium, and a stained glass window. There are blacksmiths, carpenters, joiners, boat-builders, cooper and other shops. ${ }^{32}$

HBC retirement location, Malloch may have been lured by stories about life in the north. It would not be unreasonable to suppose that he had heard tales of Dr. John Rae, who spent ten years at Moose Factory and then travelled to the Arctic in search of the Franklin Expedition. Rae, too, had close family ties in Hamilton including a nephew who became an Indian Agent in 1880. (Compiled from records of the Leeds \& Grenville Branch [Brockville, Ontario] of the Ontario Genealogy Society, Harrow Early Immigrant Research Society [Harrow, Ontario], Scott Polar Research Institute [Cambridge, England], and Jennifer S. H. Brown, Strangers in Blood (Vancouver: University of British Columbia Press, 1980); especially pages 186 and 194. As a McGill graduate, Malloch would have been aware that the University's benefactor, James MCGill, had been a prominent fur trader.

25 Malloch's 1870 manuscript letters are in the McCord Archives, M18604 (hereafter M18604).

26 I use here the language of Malloch's own account without apology.

27 William Bell Malloch, Letters, McCord Archives M18604, p.10.

28 In Mailoch's letter dated February 28, 1879 to Charles Stuart, he wrote that he had suffered badly from "Mal de Rackette" for four days (Letter from William Bell Malloch to Charles Stuart, Aesculapian Hall 28 February 1870, Archives of Ontario, MU 1399, Box 7, HBC Papers - Temiscamingue District \#6541; envelope 11 Moose Factory Fur Trade Records (-7-11). Mal de raquette is the term used to describe the intense pain caused by straining the leg muscles while snow shoeing.

29 William Bell Malloch, Letters, McCord Archives, M18604.

30 lbid.

31 Although Malloch called Hazy Island his new home (Letters, McCord, M18604, p.11), his description of Moose states that between the island [that is, Moose] and the east shore there were three islands Called "Petawanaka," "Hazy" and the "Hats" as well as a peninsula called "Mansey." On the east and south side were the islands "Charles, Saw-pit and Poplar" and "Iack's Swamp." Beyond those were islands named "Buil's Gateway, South Bluff and Bill of Portland" (|bid., 12). 
Malloch appears to have been impressed by the presence of three bells (the church bell, the officers' and the men's bells) and the role they played in structuring community life, alternately separating the social classes and then bringing them together. The men's bell rang five times: as reveillé at 6 a.m., at 7 a.m. as a signal to go to work, at noon for dinner and again at one to return to work, and ultimately at 6 p.m. to announce the end of the work day. However, in accordance with their elevated status, the officers' bell rang only three times: at 8 a.m. for breakfast, at 1 p.m. for dinner, and at 6:30 p.m. for tea. But it was the "clear sounding" church bell calling all the worshippers together which impressed him the most. ${ }^{33}$

A further instalment, revealing his now more intimate knowledge of the island, provides a detailed "walking-tour" description of Moose Factory's Upper and Lower Towns, separated by the factory itself. Beginning this imaginary tour by having his readers land at the head of Moose Island, Malloch leads them through "a pretty little grove of poplar and evergreens" to a "few scattered log cabins belonging to the resident Indians." From there we are led to the "parson's house, with gardens surrounded by a fence," and close by is the large new school house, "which," as Malloch writes, "would do credit to a place of greater importance than our humble town." The rest of Upper Town contains about a dozen detached houses complete with gardens, built for the married men.

Following the road along the river bank and past two fields, "we come to the neat little church with its shining tin spire." The church, with its stained glass window, was large enough to seat 200 worship- pers. Past this, the first house we encounter, with "every window fully occupied by choice flowers," is that of Chief Factor James Anderson. Here the officers ate their meals in the Mess Room, overseen by a "life size painting of the late Governor, Sir George Simpson, hung in a massive gilt frame." Next to Anderson's house was a tall dark building divided into three sections: offices at one end, Trader James Cotter's home in the middle, and the Guard Room and officers' quarters at the other end. Opening off the guard room was Malloch's quarters which he promptly named "Aesculapian Hall" derived from Aesculapius, the Roman god of medicine and healing. Continuing our tour past the workshops and shipyard, the unmarried men's house with attached bake- and store-houses, the barnyard and stables, and finally, the sawpit, we enter Lower Town. Located here are the houses for the married men, set back about 50 yards from the shore. According to Malloch, "The houses are all boarded on the outside and painted white, with red or green around the windows. Every house has a gallery and a garden, so that it is quite a pretty little town."

The carpenters and boat building shops with the shipyard beside them were bustling enterprises involved in building and repairing all sizes and types of boats from pleasure craft to large vessels. At the joiners' shop men were busy making window frames and doors in preparation for the new buildings to be erected during the summer. However, as Malloch mentions neither the construction of the New Factory begun in 1870 nor the removal of Old Factory, we must presume that these took place after this particular letter was written. Certainly the magni-

32 Much of what Malloch included in his manuscript appeared in at least the Ottawa Citizen and the Carleton Herald in 1870 and 1871 as printed letters. He notes in a letter to Charles Stuart that, "Unfortunately some of my friends in Canada have published some of my private letters, and it is not at all liked by the people in the Country. I am sorry that this has happened, as it will do me no good; but I have cautioned my friends not to publish anymore." (Letter from William Bell Malloch to Charies Stuart, 22 February 1871, Archives of Ontario, MU 1399, Box 7, HBC Papers - Temiscamingue District \#6541; envelope 11 Moose Factory Fur Trade Records C-7-11 "Moose Factory").

33 Ibid.

34 A photograph showing the erection of this building was published in an article by Cotter's son. H.M.S. Cotter, "Venerable Buildings at Moose Factory," The Beaver 259 (December 1928): 121-22. 
tude of the framework - described as twelve- by-twelve timbers all solidly bolted together and photographed by James Cotter - would have overshadowed the older building. ${ }^{34}$ While Chief Factor James Anderson was both the architect and the contractor, its solid construction served as a long lasting tribute to the craftsmanship of the local English, Scottish and native carpenters. Such men as Angus Faries, Alexander King, John King, George Linklater and William McBean may have been among the carpenters working towards completion in 1871. The subsequent demolition of the Old Factory with its lead roof, embattlements and brass cannon marked the end of an era when protection against French incursions was no longer needed.

On August 25, 1870, presumably in response to queries from readers and/or relatives in Canada, Malloch composed a brief overview of the climate, the soil, and mineralogy of the area. Much as we would like an insight into his own reactions to the extremes of temperature, he speaks quite impartially about the winter of 1870 when the weather had been unusually cold with a low of $48^{\circ} \mathrm{F}$ below zero. This severe cold was followed by an early spring whereby "the river broke up on April 21st" instead of the first week in May as was normal. By June the thermometer had hit $100^{\circ} \mathrm{F}$ in the shade and this hot dry weather continued until the beginning of July when rain and cooler temperatures brought some relief. Violent storms throughout the territory left at least five dead and others injured at Mistassini. ${ }^{35} \mathrm{Had}$ we been privileged to read his later letters, we might have been told of the distant shock of an earthquake felt on the forenoon of October 20,1871. ${ }^{36}$
The native inhabitants of the community were described as being fond of flour, oatmeal and quantities of tea, and as willing workers evidenced by voluntarily cutting timbers and laying the foundations of the new school house. ${ }^{37}$ Nominally Christian, and at that time, exclusively members of the Church of England (Anglican), they were decorous and regular in their attendance at church. However, there remained a few who clung to their ancient beliefs. The names found in the Parish records ${ }^{38}$ for deaths and baptisms provide the composition of the Christian community. Many of the names, both British and Cree, and with variant spellings, still occur in the Moose Factory region: Turner, Checho, Linklater, Job, Morrison, Smallboy, Hunter, Sailor, Anderson and Faries. Baptismal records, established under the patriarchal and hierarchal system of the Church of England, register the "Quality, Trade or Profession" of the infants' fathers. Carpenter, cooper, servant (that is, HBC employee), doctor, labourer or "Indian" fall equally within this category.

During the 1870 s, the non-native men in charge of Moose Factory included Chief Factor James Anderson who was there when Malloch arrived. Anderson was replaced first by James Stewart Clouston (1870-73) and then George Simpson McTavish (1873-74) with his wife. Subsequently, Factor Alexander McDonald served during 1874-75 until his death at which time the position was assumed by Chief Trader (later, 'Factor') Samuel K. Parson (1875-1879). ${ }^{39}$ In charge of the religious life at Moose, The Rev. (later, 'Bishop') John Horden and family had been there since 1851 and through their

35 Letter from Rev. John Horden to CMS Lay Secretary, 8 September 1870, Church Missionary Society, Mg17, vol.B2; reel A-80 1868-1876, p 217 (microfilm).

36 McMillan James Goldie, Investigations at James Bay During 1912, Temiskaming and Northern Ontario Railway Commission Report No.3 (Toronto: L.K. Cameron, 1913), 59.

37 Letter from Rev. John Horden to E. Hutchison, Esq., 28 January 1870, Church Missionary Society, Mg17, vol.B2; reel A-80 18681876, p 161 (microfilm).

38 Anglican Church, Diocese of Ontario, National Archives of Canada, MG17,B6, 1864-1916, reels M3697-M3704 (microfilm). 
efforts other young missionaries were introduced to the field, among them the Reverends J.H. Keen, who arrived in 1875 and E.J. Peck in 1876. Numerous outside visitors, such as Robert Bell, Fleming's survey team, and Governor James Grahame, arrived during the summer months while men from other posts came throughout the year, often unidentified and unrecorded in the diaries and letters of the Moose Factory residents.

\section{MOOSE FACTORY AND CANADA}

Long an important $\mathrm{HBC}$ trading post, Moose Factory also served as a major port in the exportation of furs to England and the import of goods and company personnel. From 1751 to 1880 , at least one ship arrived at Moose Factory every single year without failure. ${ }^{40}$ After the amalgamation of the two major fur trading companies - the HBC and the North West Company - in 1821, Moose Factory served as the HBC headquarters and supply base for the Southern Department encompassing the area drained by the rivers flowing into eastern and south-eastern $\mathrm{J}$ ames Bay. Although the HBC's "exclusive right of trade" terminated and Rupert's land was surrendered to the British Crown, which in tum transferred the land to the Dominion in 1870 , the Company retained ownership of its trading posts and adjoining lands. Consequently, trade during the 1870 s continued as completely in the hands of the Company as it was before $^{41}$ and the HBC's annual ship still served as the most practical access to Moose Factory. Further disputes between the Ontario and the Dominion governments focussed on the Moose Factory district as the "largest, most advanced settlement in the eastern portion of the territory" 42 with the district awarded to Ontario by arbitration in 1872. Coupled with these political changes, Moose Factory also became the episcopal seat of an immense diocese extending some two to three hundred miles to the east, south and west. The Rev. John Horden was consecrated as the first Bishop of Moosonee in 1872.

Both these changes brought disturbing concerns. On September 21, 1875, Canadian Customs increased costs considerably by adding $17 \%$ to cost price. By February 8, 1876 tariffs levied on goods brought in from Canada had risen to a monumental 50\%. As this sorely affected the community, Horden requested a reduction. With success in that quarter Horden then became concerned about the impact of Roman Catholics at Michipicoten and Temiskamingue, worrying that "both gates leading from Hudson's Bay to Canada are in the enemy's hand." 43 Without addressing specifics, Chief Factor Alexander MacDonald of Albany mused about the changes brought about by the Canadian Government in a letter dated 28 January $1872^{44}$ to Charles Stuart at Temiscamingue and asked Stuart what he thought of the New Venture:

Well what do you think of it? for [sic] by this time you have been posted up fully in the program \& know what we shall all be about - Icannot say that I am very anxious,

39 Eric Arthur, Howard Chapman and Hart Massey, Moose Factory 1673-1947 (Toronto: University of Toronto Press, 1949).

40 I.B.Tyrrell, "Arrivals and Departures of Ships. Moose Factory, Hudson Bay, Province of Ontario," Ontario Historical Society Papers and Records 14 (1916): 163-68. While Malloch was at Moose Factory the ships were the Lady Head, captained sequentially by John James, G.B. Galbraith and Henry Bishop; the Ocean Nymph, captained by Henry Bishop; and the Prince of Wales, captained by Henry Bishop.

41 E.B. Borron, Report on the Basin of the Moose River (Toronto: Warwick and Sons, 1890), 74

42 Morris Zaslow, "Rendezvous at Moose Factory, 1882," Ontario History 53, no.2 (1961): 81

43 Letter from Rev. John Horden to CMS Lay Secretary, May 2, 1876, Church Missionary Society, Mg17, vol.B2, reel A-80 18681876 (microfilm)

44 Letter from Alexander MacDonald to Charles Stuart, Albany January 28, 1872, Archives of Ontario, MU 1399; Box 7; H.B.C. Paper - Temiscamingue District \#6541, envelope 2, Albany Fur Trade Records C-7-2. 
but at the same time I am not atall [sic] sanguine that our circumstances will be very materially improved by the change; a change however even though it be for the worse is better than the doubt \& uncertainty we were labouring under while "running the old machine."

During Malloch's tenure in Moose Factory during the 1870 s, a number of other national events took place which ultimately had some effect on those in isolated areas: the fur-trading district of Assiniboia became the Province of Manitoba on July 15, 1870; British Columbia became Canada's sixth province in $1871 ;{ }^{45}$ closer to home, one of Sandford Fleming's survey parties, exploring the country along the Abitibi and Moose Rivers for a northern route for a railroad, went as far as Moose Factory in the summer of 1871 ; the transcontinental railway was being built to link the new nation together and to provide easier access to remote areas; the North-West Mounted Police came into being in 1873; in 1873 Prince Edward Island also agreed to join the Dominion; and the fall of 1873 witnessed the forced retirement of Sir John A. MacDonald and Liberal leader Alexander Mackenzie replaced him as prime minister. These changes exacerbated an already declining fur trade. Despite the political and economic changes which inevitably occurred once Rupert's Land became a part of Canada, the effects of nature on subsistence practices, health, and travelling remained relatively unchanged during the 1870 s.

\section{MALLOCH'S LIFE AT MOOSE FACTORY}

Life in the north, far from the academic stimulation of McGill, the cultural exhilaration of urban Montreal, and the warmth and support of a closeknit family in eastern Ontario demanded a strength of character which Malloch had already demonstrated in coping with the trials and tribulations of his trip to Moose Factory. Isolation from southern amenities on one hand and the insularity of the small northern communities on the other impose tensions at both the individual and group levels. Thus, pleasures derived from earlier pastimes and the development of new ones, along with new contacts and shared interests ameliorate these stresses. Malloch, for one, demonstrated a lively enthusiasm, an eagerness to participate in Moose activities, and a repertoire of interests suitable for dispelling boredom and anxiety. As early as 28 February 1870 , Malloch wrote to Charles Stuart at 'Temisgamingue, thanking Stuart for his recent kindness and remarking that, "I like Moose very well, and think I will get on very well here." 46 A second letter to Stuart relates the pleasure of goose hunting at Albany and although the hunt was poor, he enjoyed the camaraderie of Thomas Vincent and $\mathrm{Mr}$. Broughton. ${ }^{47} \mathrm{His}$ marriage in 1872 and the subsequent births of his children added immense pleasure to his life at Moose.

Outside his medical practice, his additional duties as a "very efficient officer, [with] sound judgement and regular business habits," 48 and his social

45 As Chief Survey of the continental railway, Sandford Fleming's request to the officers of the HBC for a letter of introduction for the members of his surveying expedition to James Bay was granted by James Bissett in a letter dated Montreal 19 th June 1871 (Letter from James Bissett to Sanford Fleming, 19 June 1871, HBCA B.134/b/30, fo.641). See also Fleming's Report on Surveys and Preliminary operations on the Canadian Pacific Railway up to January 1877 (Ottawa: MacLean, Roger \& Co., 1877), 47-48.

46 Letter from William Bell Malloch to Charles Stuart, Aesculapian Hall February 28, 1870, Archives of Ontario, MU 1399; Box 7; H.B.C. Paper - Temiscamingue District \#6541, envelope 2, Moose Factory Fur Trade Records C-7-2 0.

47 Letter from William Beil Malloch to Charles Stuart, Moose Factory February 22, 1871, "Archives of Ontario, MU 1399; Box 7; H.B.C. Paper - Temiscamingue District \#6541, envelope 2, Moose Factory Fur Trade Records C-7-2.

48 As cited in a four-page account from the Search File of the HBCA as compiled by Judith Hudson Beattie, Keeper of the Hudson's Bay Archives. 
obligations, Malloch delighted in a number of interests and activities. A nascent interest in horticultural becomes apparent with discussions about the fertility of the soil, detailed accounts of crop yields and several references to the abundance of flowers, both wild and domestic, annual and perennial. About these he writes: "I have never seen finer house flowers in a green house. They seem never to stop blooming, and the flowers are in large numbers." ${ }^{49}$ The summer of 1876 was particularly pleasant and fruitful: "early rose potatoes in one of our fields gave a return of 23 for 1 of seed planted [and] we had a very fine show of both garden and house flowers." ${ }^{50}$ That summer was also the first time Malloch had succeeded in "bringing tomatoes to perfection." 51 According to curt notes recorded by James R. Nason, $\mathrm{HBC}$ accountant and meteorological officer at Moose, ${ }^{52}$ this interest in growing things developed into botanical exchanges between the two men from digging flower gardens in May to the presentation of a lily to Nason from the doctor. Interest in growing things also encompassed detailed observations concerning the collecting and transporting of wild water hay for the cattle, oxen, and horses. ${ }^{5.3}$

During the winter of 1876 , the "mania for working on the turning lathe" enthralled Malloch as it did his friends in the community. Using a "very fine little lathe, made by Fenn, [1] have been able to turn out some very fair work in ivory." ${ }^{\prime 4}$ By 1878 , he and Samuel Parson were doing "a great deal of turning and have had great success." 55 Although many of the ivory pieces in the collection appear to be Inuit in form and material, and are identified as having been made by the Cree, they may, in fact, be examples of Malloch's work.

Malloch's second published letter discloses his interest in, and proficiency at, photography by expressing regret that he was not able to send good photographs of Moose Factory as it was "too early in the season to take good negatives in the open air." Furthermore, he hoped "to take a panoramic view from one of the islands" in a week or two (Fig. 5). The few views of Moose Factory which he did send with that second letter were printed on ordinary notepaper which he "albuminized" himself as there was a shortage of commercially-prepared albumen photographic paper. ${ }^{56}$ Much later, in writing from Ottawa to Robert Bell, Malloch mentioned that he had "a large collection of photographs in the Indian and Esquimaux country" which Sydney Hall of the Graphic sent to that paper. ${ }^{57}$ At the time of his letter, Malloch was still waiting to see them in print, but reflected

49 William Bell Malloch, Letters, McCord Archives, M18604.

50 Letter from William Bell Malloch to Robert Bell, 20 January 1877, National Archives of Canada, MG29, B1 5, v.26, Correspondence to Robert Bell: "Malloch W.B. [Moose Factory] 1875-79".

51 lbid

52 Anonymous, "William Nason of Weston, 1818-1890," York Pioneer, 1964, p.62-69. As well, biographical information from the Papers of the Borough of York, York University Archives (on Search File "James R. Nason"), states that James Randle Nason matriculated at the College of Physicians and Surgeons of Ontario in July of 1872. The following year (1872-73) he spent at McGill Medical Faculty. Nason, it seems, preferred conducting meteorological observations rather than practicing medicine.

53 Malloch, Letters, McCord, M18604

$54 \mathrm{Ibid}$

55 Letter from William Bell Malloch to Robert Bell, 15 August 1878, National Archives of Canada, MC 29, B15, vol. 26, Correspondence to Robert Bell: "Malloch W.B. [Moose Factory] 1875-79".

$56 \mathrm{M} 18604$.

57 Letter from William Bell Malloch to Robert Bell, 20 January 1877, National Archives of Canada, MG29,B15, v.26, Correspondence to Robert Bell: "Malloch W.B. [Moose Factory] 1875-79" 
that "with two wars, Royal marriages, etc., they [the Graphic| have as much as they can manage." 58

This early interest in photography led him to be included as one of the members of what is now known as the "Moose Factory Group" comprised primarily of Malloch, Bernard Rogan Ross, James Anderson, Charles George Horetzky, James Cotter and George Simpson McTavish. ${ }^{59}$ Certainly, this photographic interest was shared with Cotter and possibly McTavish, as all three men were resident at Moose Factory together. As it was not a common practice to sign photographic prints and there was much sharing of prints, attribution for many of the photographs remains unclear. Many photographs in the Malloch collection in the Notman Photographic Archives appear to have been taken by Cotter. Indeed, the current catalogue description for the photographs (AppM64/36) notes that the "portraits of Esquimaux and views in Hudson's Bay are from the collection of Dr. W.B. Malloch ... [but were] taken by an Officer in the Hudson's Bay Company's service."

Hints of Malloch's impending marriage are noted first in Malloch's letter to Charles Stuart ${ }^{60}$ at Temiskamingue requesting lodging and then transportation from Mattawa on his trip back to Canada and confirmed in A. MacDonald's letter of 28
January 1872, also addressed to Charles Stuart, in which he mentions that the doctor was going back to Canada that winter "for the purpose of getting married." "61 At "Beech Grove" in Ottawa on 25 April 1872 Malloch married his first cousin, Mary Stewart Malloch, youngest daughter of the late Edward Malloch M.P. ${ }^{62}$ Prior to leaving for their trip northward by canoe, the Mallochs sat for several photographic portraits (Fig. 6) at the Notman Studios in Montreal, including one of Dr. Malloch resplendent in Cree clothing and posed with Cree snow shoes (Fig. 2).

Marital bliss was cruelly interrupted by the premature birth on 24 November 1872 of a daughter who lived a mere 14 hours. In the absence of Reverend Horden, the infant was laid to rest by Chief Factor James Clouston. Happily, any prolonged mourning was quickly dispelled by the birth of a son on 3 August 1874 and a daughter on 3 September $1875 .{ }^{63}$ Bishop Horden baptized each of the infants. ${ }^{64}$ While disclaiming any partiality, Malloch's obvious pride in his own children contradicts such an assertion. In a letter to Bell dated 14 January 1875 , he writes: ${ }^{65}$

Stewart Ernest Malloch is now nearly 6 months old, and with out [sic] speaking of him with the partiality of a

58 lbid.

59 A. J. Birrell, "The Early Years, 1839-1885," in Private realms of Light: Amateur photography in Canada, 1839-1940, ed. Lilly Koltun (Markham, Ontario: Fitzhenry \& Whiteside, 1984), 1-15.

60 Letter from William Bell Malloch to Charles Stuart, Moose Factory 17 July 1871, Archives of Ontario MU 1399; Box 7; H.B.C. Papers, Temiskaming District \#6541, Envelope 11 Moose Factory. Fur Trade Records C-7-11.

61 Letter from Alexander MacDonald to Charles Stuart, Albany 28 January 1872, Archives of Ontario MU 1399; Box 7; H.B.C. Papers, Temiskaming District \#6541, Envelope 2 Albany. Fur Trade Records C-7-2.

62 As recorded W.B. Malloch's Bible under the heading "Register of Marriage."

63 The births of the Malloch children were recorded in Malloch's Bible under the heading "Register of Berths [sic]" and the infant's death under "Register of Deaths."

64 Stewart's August 23rd baptism was "solemnized in the Parish of St. Thomas in the Diocese of Moosonee in the year One thousand eight hundred and Seventy four [sic]" by "John Moosonee." Anglican Church. Diocese of Ontario. National Archives of Canada, MG17,B6, 1864-1916, Mf reels M3697-M3704 (microfitm).

65 Letter from William Bell Malloch to Robert Bell, 17 January 1875, National Archives of Canada, MC29,B15, v.26, Correspondence to Robert Bell: "Malloch W.B. [Moose Factory] 1875-79". 
father, I can say he is as fine a boy as l ever saw-strong, healthy, rosy cheeked, and full of mischief at his present age. When he laughs he is a miniature of what my father was when enjoying a hearty laugh.

Then, exactly thirteen months later, Mrs. Malloch made him "proprietor of a little daughter... called Alice Muriel [whol is now nearly 5 months old, and is a bright laughing little thing." 66 In the same letter, Malloch notes with certain pride that Stewart began to walk shortly after Bell's visit to Moose Factory, and can now say "almost any word, and is beginning to form sentences." Just short of two years, Stewart's precociousness in speaking is duly noted: "I never knew a child of his age talk as distinctly as he does. He can give you a dissertation on Barometers and Thermometers."67 "Mrs. Malloch always has her hands full looking after the house and the children." 68

Stewart's inquisitiveness is evident at an early age. At eighteen months he was not to be deterred from entering his father's surgery where he delighted in "eating spermaceti ointment, cold cream, and such like." 69 This same curiosity led to burnt fingers at age two-and-a half years. From Nason's cryptic notes we are apprised of Stewart's mishap in burning his fingers but are given no details how this came about. None of this undermines Malloch's delight in his children for later, as one father to another upon learning of the birth of the Bells' daughter, he confides to Bell that "It is oniy in children that married people have true happiness." 70

The presence of the Church of England in Moose Factory played an instrumental role in the social life of the non-Native community. Not only did the mission provide sacred education and guidance to the entire community, both native and non-native, it was the locus of virtually all secular social activities for the class-conscious elite, both religious and lay persons. So strong was the influence, and so solid was this group that it is not surprising to find mention of James Nason taking Communion for the first time nor that both Dr. and Mrs. Malloch forsook their staunch Presbyterian upbringing to become confirmed as Anglicans. On July 23, 1873, Dr. Malloch became one of the first group confirmed by Horden's as Bishop of Moosonee. Bishop Horden noted at that time that, of the sixteen confirmed at the English service, all were "half-castes with one exception, our medical man, a gentleman from Canada, originally a Presbyterian, who had for some time a strong desire to be connected with the English Church." 71 Mrs.

66 Letter from William Bell Malloch to Robert Bell, 1 January 1875, National Archives of Canada, MG29,B15, v.26, Correspondence to Robert Bell: "Malloch W.B. [Moose Factory] 1875-79".

67 Letter from William Bell Malloch to Robert Bell, 22 July 1876, National Archives of Canada, MG 29, B15, v.26, Correspondence to Robert Bell: "Malloch W.B. [Moose Factory] 1875-79". Malloch also notes in this same letter that Alice, at nearly 11 months, neither walks nor talks yet, and is far less trouble than Stewart was at the same age.

68 Letter from William Bell Malloch to Robert Bell, 20 |anuary 1877, National Archives of Canada, MC29, B15, v.26, Correspondence to Robert Bell: "Malloch W.B. [Moose Factory] 1875-79"

69 Letter from William Bell Malloch to Robert Bell, 25 January 1876, National Archives of Canada, MG29, B15, v.26, Correspondence to Robert Bell: "Malloch W.B. [Moose Factory] 1875-79".

70 Letter from William Bell Malloch to Robert Bell, Ottawa, 19 April 1879, National Archives of Canada, MC29, B15, v.26, Correspondence to Robert Bell: "Malloch W.8. [Moose Factory] 1875-79"

71 Rev. John Horden, Journal, Church Missionary Society, National Archives of Canada, Church Missionary Society, MG17, B2; reel A-99 (microfilm).

72 lames Nason noted in Moose Factory Mission Church Records, 25 December 1877, Trent University Archives, SET 10; B-74015. Dr. Malloch was confirmed on 7 September 1873 by "the Rt. Rev. Dr. Horden, First Bishop of Moosonee, this being his first Confirmation." At the English Service on 20 lanuary 1878 Mrs. Malloch was Confirmed. Moose Factory Mission Church Records; Trent University Archives, SET 10; B-74-015. 
Malloch was confirmed later at a special English service on 20 January $1878 .{ }^{72}$ Religious texts in the form of Watt's First Catechism in Eskimo, a prayer Book, a Hymn Book belonging to Bishop Horden, and a book entitled Lectures in Rhetoric, once the property of Dr. and Mrs Malloch and now in the McCord, attest to their devotion (see Appendix II).

The social life in Moose Factory ranged from a companionable smoking of cigars and pipes and week-long hunting and fishing trips with male friends to joyous celebrations of weddings, birthdays, and probably baptisms. ${ }^{73}$ Both Beatrice Horden's fourteenth, and Stewart Malloch's third, birthday parties included James Nason as one of the guests. ${ }^{74} \mathrm{Cer}$ tainly, the marriage of the Hordens' second daughter Chrissie (Christina) to HBC Trader, William R. Broughton on September 14, 1876, was a social highlight in this small community. The presence of Mrs. Malloch, Mrs. McTavish (wife of Chief Factor George Simpson McTavish), and the Horden's daughter led Bishop Horden to comment:

There was formerly no Society here, now we have some European or Canadian ladies; and my house is the only one to which they can resort from the Barrack sort of life they have lat] the H.B.C'S [sic/establishment; and seeing how much I am dependent on the H.B.C's [sic] Gentlemen throughout the country: I cannot refuse either to them or the members of the Moose staff occasional hospitality. I may add that every gentlemen [sic] and lady here is a Communicant of our Church. $^{75}$

Fortunately, Mrs. Malloch and Mrs. McTavish became close friends, so close in fact, that when the McTavishes went to [Colborne, Ontario] Canada on sick leave ${ }^{76}$ in the Autumn of 1874 , Malloch commented that his wife "misses Mrs. McTavish very much as they were almost like sisters." "77 Sadly, for Mrs. Malloch, the new Chief Factor, Alexander MacDonald, was a bachelor.

Lesser "celebrations" occurred in recognition of "firsts": first goose of the season; first eggs; first tea without having to use a lamp; first peas for dinner; the first strawberries of the season; first tomatoes; first arrival of ships; and so on. ${ }^{78}$ Other small pleasures included skating, sleigh rides, "bul.. hunting" (the chasing down of cattle who became wild after a summer of pasturing undisturbed on an island), whist parties, reading books held by the James Bay Library, ${ }^{79}$ boarding the visiting ships, making natural history collections, and meteorological observations. ${ }^{80} \mathrm{As}$ well, contact with the world outside the socially-

73 Malloch smoked both cigars (Notman Archives, McCord Museum, App M 65/36) and a buttonhole pipe (McCord Archives, M18583). Nason regularly records that there was 'good' skating

74 James Nason, Diary, 16 November 1876; 3 August 1877, Papers of the Borough of York, File "lames R. Nason", York University Archives.

75 Letter from Rev. J. Horden to Lay Secretary, 11 September 1872, National Archives of Canada, Church Missionary Society, MC17,82; reel A-80, p. 228 (microfilm).

76 Hudson's Bay Company Archives, A.11/47, fos.96,97; Letter from Alexander MacDonald to Armit, 3 September 1874, Hudson's Bay Company Archives, B.135/g/56; D.13/8, p.40

77 Letter from William Bell Malloch to Robert Bell, 1 January 1875, National Archives of Canada, MC29,B15, v.26, Correspondence to Robert Bell: "Malloch W.B. [Moose Factory] 1875-79".

78 Most of these examples are taken from lames Nason's diary; op. cit. note 74.

79 Letter from Georgie Parsons to Armit, 7 February, 1877, Hudson's Bay Company Archives, A.11/47, fo.133.

80 Leisure activities recall similar ones enjoyed at York Factory and discussed at iength by Michael Payne, The Most Respectable Place in the Territory: Everyday Life in Hudson's Bay Company Service York Factory, 1788-1870 (Ottawa: Canadian Government Publishing Centre, 1989), 65-92. 
isolated community necessitated copious letter writing, at times considered a chore by many but the only way to ensure an influx of letters in return.

\section{HEALTH AND WELFARE AT MOOSE FACTORY}

Moose Factory was the only Hudson's Bay post to have a Medical Officer during this time period. ${ }^{81}$ Having been without a doctor for a year or two, compounded by the hasty departure of the previous doctor, a certain urgency can be detected in the letters leading up to Malloch's appointment. Although an appointment for a medical officer had to be initiated by the HBC, it was certainly Rev. John Horden's letters to the Lay Secretary of the Englandbased Church Missionary Society (hereafter CMS) which demonstrated the need. In his letter of 1868 , Horden laments that he was "very busy as 'doctor" for there was a great deal of sickness and no medical man." 82 The summer of 1869 saw an epidemic of typhus fever at Abitibi to the south, when about 60 natives died and the others dispersed in fear. In the January 28th letter for 1870 , he noted "sickness abounding" 83 without identifying either the actual illnesses or whether the patients were native or nonnative. However, from the cause of death listed in the records for Moose Factory for 1868 and 1869, there is strong likelihood that tuberculosis was a prevalent cause as slightly more than 50 percent of the deaths are listed as being from various forms of that disease. ${ }^{84}$ While cause of death, of course, does not reveal short-lived or seasonal illnesses, the large number of tubercular deaths suggests that people were suffering from contagious respiratory infections and/or climatic fluctuations. ${ }^{85}$ However, Horden's reports to the Home Secretary of the CMS for 1872 and 1873 , stating that the community had been free of illness "to a wonderful degree" and deaths were few, gave credit to God, not to Malloch. 86

The high number of deaths (that is, 19) occurring at Moose Factory in 1869 was never repeated while Malloch was in residence there. Certainly the demographics during that period do not suggest any serious epidemics or lowered birth-rate resulting from reduced diets. Compiled from the Church Records of St. Thomas Anglican Church in Moose Factory, there were 70 deaths in the community over the nineyear span from 1870 to 1878 . The years 1873 and 1876 each had twelve deaths with consumption and fever being the leading causes and others being from accident, old age, and drowning. Further sampling of these records reveals that during the last three years (that is, 1876-1878) there were 49 baptisms which, in general terms, corresponds to the birth rate, but

81 E.B. Borron, Report on the Basin of the Moose River (Toronto: Warwick and Sons, 1890), 83.

82 Letter from Rev. John Horden to Rev. J. Mee, Secretary, 24 January 1868, Church Missionary Society, C. l/M Mission Books (Incoming Letters) 1868-1876, National Archives of Canada, MG 17, B2; Reel A-80 (microfilm).

83 ibid.

84 Of the eight deaths in 1868, at least four were from consumption (that is, tuberculosis). Similarly, of the nineteen deaths in 1869, nine were attributed to consumption. Ontario Archives, Vital Statistics, RC 80-10, Deaths.

85 A lengthy discussion of the causes, symptoms and treatment for consumption (pulmonary tuberculosis) is given in an early publication, The Practical Home Physician and Encyclopedia of Medicine, by Henry M. Lyman, Christian Finger, H. Webster Jones, and W.T. Belfield, (Guelph, Ontario: The World Publishing Co., n.d.): 141-160. Further information is provided by R.V. Pierce, The People's Common Sense Medical Adviser, (Buffalo, N.Y.: The World's Dispensary Printing-Office and Bindery, 1877), 468, 487, 490

86 Letter from Rev. John Horden to Lay Secretary, 1872, Church Missionary Society, C.I/M Mission Books (Incoming Letters) 1868 1876, National Archives of Canada, MC17,B2; Reel A-80 (microfilm). Also, we must keep in mind that Horden was reporting to the CMS, the source of his own livelihood. 
which also reflects the swelling of the population as the inland natives came into the community during the summer months.

The references to Malloch's role as a physician at Moose and in the other coastal posts are rather scant, leaving an obvious lacuna in our knowledge of medical practices in the north. His duties have not been spelled out in the written evidence, and must be compiled from scattered sources. His first patient was Mrs. Charles Stuart whose tooth he extracted during his visit at Temiscamingue on his initial trip in 1870.87 In January of 1872 he accompanied Mr. McTavish back from Albany to attend to Mrs. McTavish's undisclosed illness, and he was the attending physician when Chief Factor Alexander MacDonald died at age 45 from "softening of the brain" in 1875. From Malloch's letters to Bell, we are informed that James Cotter suffered from sore eyes (later identified as ophthalmia tarsi) which, presumably, was contagious as Malloch noted that he, too, suffered an attack. ${ }^{88}$ Apparently Stewart was very sick at Christmas time with an intermittent fever similar to that which Georgie Parson was recovering from at the time of the correspondence. As all these patients were $\mathrm{HBC}$ people, it is not clear whether or not he went beyond company policy attending to the medical needs of the Cree as well as those of $\mathrm{HBC}$ officers and servants. ${ }^{89}$ During the first month or so of 1877 Malloch noted that "nearly every child has been through my hands." 90 Given the small size of the community, most, if not all of these children would be Cree and/or of mixed ancestry. An incident recorded in Malloch's letter to Bell dated 15th February 1878, describes at length an amputation he had performed on an Indian who had been shot accidentally just above the elbow. With great haste and a team of four dogs Malloch travelled due south for 25 miles until he reached their temporary camp on the second day. After moving the man to Moose, Malloch was assisted in the amputation of the shattered arm by Dr. Horden (Bishop Horden's son) who administered the chloroform while the Bishop, Mr. Spencer, and Tom Morrison threaded needles, handed knives, scissors, sponges, and so on. ${ }^{91}$ Another of Malloch's duties was to write certificates for $\mathrm{HBC}$ men requiring leave or release from service. Accordingly, in 1875, Thomas Flett, suffering from an Inguinal Hernia, was deemed "unfit for the duties of this country." ${ }^{\prime 2}$ Similarly, Malloch wrote that Angus McDonald, Donald McMillan, and Ralph Goodwin were unfit for service due to medical reasons. ${ }^{93}$

Even if Malloch did not provide medical care for the natives, he certainly observed their illnesses and diseases, ${ }^{94}$ for in a paper read before the Bathurst and

87 Malloch extracted Mrs. Charles Stuart's tooth while he was staying with them at Temiskamingue. (Letter from Aesculapian Hall 28 February 1870, Archives of Ontario, MU 1399; Box 7; H.B.C. Paper-Temiscamingue District \#6541, envelope 2, Moose Factory Fur Trade Records C-7-2.

88 Letters from William Bell Malloch to Dr. Robert Bell, 22 January 1877; 13 February 1877, National Archives of Canada, MC29, B15, vol.26, Correspondence, "Malloch, W.B. [Moose Factory] 1875-79". Apparently ophthalmia was common among Indians further west (lody Decker, "Surgeons' Stories: The Reports of the First Doctors of the NWMP," The Beaver 78, no.3 (1998): 24-27.

89 According to Blythe, Brizinski and Preston, although the HBC retained medical officers, they may have provided little health care to the Native population. (Blythe et al, "I Was Never ldle", see note 26).

90 Letter from William Bell Malloch to Robert Bell, 20 January 1877, National Archives of Canada, MG29,B15, vol.26, "Malloch W.B. [Moose Factory] 1875-79".

91 Letter from William Bell Malloch to Robert Bell, 15 January 1878, National Archives of Canada, MC29,B15, vol.26, "Malloch W.B. [Moose Factory] 1875-79".

92 Hudson's Bay Company Archives, B.135/z/4, folder 3, to. 23.

93 Hudson's Bay Company Archives, B. 135/2/4, folder 3, fos. 24,25, 26

94 See also Payne, The Most Respectable Place, 99. 
Rideau Medical Association in 1885, Dr. Robert Bell provided greater detail about these diseases having drawn upon his own lengthy "exposure to the diseases of Indians and Eskimos" coupled with that of other medical men including "the late Dr. Wm. Malloch, who resided some 8 years at Moose Factory." In this paper Bell revealed that various respiratory diseases such as pleuro-pneumonia, capillary bronchitis, "inlanders cold," and whooping cough were common, often running "rapidly through the whole settlement." 95 Whooping cough, in particular, was rampant at Albany and Moose on more than one occasion, being especially fatal to the Indian children. For the most part, there was little that the physician could do. Bell further noted relatively few occurrences of circulatory or urinary problems, scrofula - a form of tuberculosis which "manifests itself in many ways," 96 fevers, small pox, scurvy and syphilis, but greater frequencies of decayed teeth and toothaches in the native populations. As for their general well-being, physical deformities, life-span, and reproduction, Bell remarked that there were few old Indians, still fewer cases of spinal curvature, and that extensive walking and other fresh-air activities made gestation and parturition an easy matter for the women. Most ailments, both physical and mental, were healed through a reliance on herbal remedies and/or the spiritual intervention of shamans. ${ }^{97}$

Medical practice in the Bay area, as provided by the $\mathrm{HBC}$, would have been no better than, and per- haps not as good as, that found throughout Canada. According to our standards of today, medical practice during the 1870 s could be considered rather primitive with staggering infant mortality from diphtheria, whooping cough, measles, typhoid, smallpox and polio. Despite the 1867 introduction of sterile conditions in surgery and the use of carbolic acid to disinfect wounds, it took a decade for this practice to be accepted universally. Even late in the 1870s doctors would carry out operations without gloves, with barely washed hands, and by holding their scalpels in their teeth when their hands were busy with something else. ${ }^{98}$ Although we do know that Dr. Bell was sending Malloch both vaccines and current medical reports, ${ }^{99}$ Malloch's actual practices remain shrouded in mystery.

The only known report on Malloch is one made by his superior, Factor Alexander Macdonald in 1875 in which he writes that, "Doctor Malloch is peculiarly qualified to fill the post he holds at this place, vitz [sic] - that of clerk \& surgeon, he caring little for his professional duties \& having a decided taste for store work." This is a provocative footnote to Malloch's career as the writer is the same Alexander MacDonald who died from softening of the brain, and whom Horden had labeled in 1874 as being "hot, hasty, and headstrong." 100 Regardless of Malloch's interests and capabilities, it is only after his retirement to Canada that Malloch himself reveals in his last letter to Bell insights and testimonials not provided elsewhere. Derived from "a great packet of letters from Moose"

95 Dr. Robert Bell, "Notes on Diseases among the Indians," Address to the Bathurst and Rideau Medical Association, january 1885 , National Archives of Canada, MC29,B15, vol. 2, file 25.

96 Ibid.

97 Bell also wrote a treatise - The "Medicine-Man"; or, Indian and Eskimo Notions of Medicine (Archives of Ontario, Pamphlet No. 31 ; Montreal: Gazette Printing Company, 1886). Bell notes that "...the common Indian notion of disease is that it is caused by some evil influence, which must be removed..." (p.7). Bell illustrates this with an anecdote (p.8) about an Indian canoe-man who fell ili. Bell nursed him for several days and when nearly better, the patient secretly called in a reputed medicine man. Following the latter's visit, the man pronounced himself cured

98 Peter Waite, "Between Three Oceans: Challenges of a Continental Destiny (1840-1900)," In The I/lustrated History of Canoda, ed. Craig Brown (Toronto: Lester \& Orpen Dennis, 1987), 279-374.

99 Letter from William Bell Malioch to Robert Bell, 15 February 1878, National Archives of Canada, MG29, B15, vol.26, Correspondence "Malloch W.B. [Moose Factory] 1875-79". 
it was apparent that "the new Doctor was not very well, and it is said he is not very sociable, and does not play Whist." The common people say "he does not give the right kind of medicine, and wish the old Doctor back." Furthermore, "I had the warmest feelings of kindness from all, and I flatter myself that all, from the officer in charge to the poorest Indian, would be glad to see me back once more." 101 This respect is tangibly recorded in the beautifully-made items acquired by the Mallochs and now part of the ethnographic collection in the McCord Museum.

\section{THE END OF A BRIEF LIFE}

On 19 August 1878, at the expiration of Malloch's second contract, ${ }^{102}$ the family left Moose Factory to return to southern Ontario by way of Michipicoten. After staying at "a beautiful country residence belonging to our family" in Perth, the young family then settled on Maria Street in Ottawa. ${ }^{103}$ Although they enjoyed several visits to Rideau Hall, it was not sufficient enticement to keep them in Ottawa. Before moving elsewhere, they planned to visit the Orkney Isles and then travel southward, perhaps as far as the Holy Land. The plans, however, came to naught, perhaps due to Dr. Malloch's illness during the autumn. Rather, they moved to Smith's Falls, and ultimately settled at Brockville, "that El Dorado of retired H.B. Officers" with Mr. Christie on one side and Mr. Crawford at a little distance on the other side. ${ }^{104}$ To add to their pleasure, the Mallochs antic- ipated a visit from the McTavishes. ${ }^{105}$ And it was in Brockville on 13 March 1881, that Dr. William Bell Malloch, at the young age of 36 years and 13 days, succumbed to tuberculosis, possibly contracted while at Moose Factory. His final resting place is with other family members in Elmwood Cemetery at Perth, Ontario.

His widow, Mary Stewart Malloch (neé Malloch) married another first cousin, Francis Stewart Malloch and moved to Hamilton, Ontario. His son, Stewart, also died at an early age, being merely 31 years old at the time of death, and was interred in Hamilton in 1905. His daughter Alice, who married Mr. W. Angus Murray, was the generous donor of the Malloch collection which has proven to be so valuable.

\section{MALLOCH'S LEGACY}

William Bell Malloch left a wonderful legacy: to Stewart the gold pocket watch, chain and seal he had received from his own father as well as a turning lathe, other tools and a double barrelled gun; to Alice whatever items his widow chose to select from his personal and/or medical professional books and instruments to be equivalent to the goods bequeathed to Stewart; money, property and goods to his widow Mary Stewart Malloch. ${ }^{106}$ His will also contained explicit directions that both children were to receive as liberal an education as possible. It was his express wish that his son enter a profession, while his daughter was

\footnotetext{
100 Letter from John Horden to Wright, 5 May 1874, National Archives of Canada, Church Missionary Society, C.I/M Mission Books (Incoming Letters) 1868-1876, vol. B2; Reel A-80.

101 Letter from William Bell Malloch to Robert Bell, 19 April 1879, National Archives of Canada, MG 29,815, vol. 26 Correspondence to Robert Bell: "Malloch W.B. [Moose Factory] 1875-79"

102 HBCA B. $135 / \mathrm{g} / 60$.

103 Letter from William Bell Malloch to James Bissett, 19 October 1878, HBCA B.134/C/139, fo. 221

104 Letter from William Bell Malloch to James Bissett, 24 November 1879, HBCA B.134/C/142.

105 Ibid.

106 William Bell Malloch's last will and testament was drawn up and signed in Smith Falls, Lanark County on 29 May 1879. Upon Malloch's death his executors, Mary Stewart Malloch and Edward Crookshank Malloch, made application for probate which was granted 28 April 1881 pursuant to an amendment to the inventory of goods and monies by Mary Malloch.
} 
to be sent to England or Scotland for her education.

Unbeknownst to Malloch when the will was drawn. up, these bequests had far-reaching effects when the artifacts, photographs and papers became available to the public through the donation to the McCord Museum. This latter legacy, passed on primarily by Malloch's daughter, yields glimpses into an earlier time in Canadian history: the Scots immigrant settlement with its emphasis on Presbyterian principles and strong family values; the intertwining connections of a social elite, many of whom gained their education at McGill University; the nexus of native and non-native cultures; vignettes of life at Moose Factory in the 1870 s, and the marvellous substantive evidence of Cree material culture in Moose Factory at that time. Certainly, of these legacies, the most significant are these latter artifacts.

These few, but exquisite, items made at Moose Factory by Cree women and men during the 1870 s represent one of the very few documented collections of James Bay Cree material. From it we can ascertain what was worn, the materials used, the techniques employed, the level of expertise of the makers, and most significantly, specific motifs, colour choices, and styles in that region at that time (Figs. 7-12). A number of features are particularly important. For example, the presence of both silk embroidery and beadwork to decorate finely scraped, brain-tanned caribou hide demonstrates the overlapping of these decorative techniques. As well, illustrated in the photograph of young Stewart (Fig, 3 ) is a panel bag with a loom-woven bead panel which establishes Moose Factory as one community of origin for this type of bag. Alice's mittens (Fig. 8) reflect European influence in their cut and two-button closure. In contrast, Stewart's fur-trimmed and ornamented pair is more typical of the James Bay region. The photograph of Dr. Malloch (Fig. 2) shows him wearing what has been assumed to be a malestyle of legging with a deep-notched ankle area (similar to two pairs held by the McCord). This photograph is the only known example corroborating this assumption. ${ }^{107}$ As well, his painted Cree snow shoes recall a decorated pair collected prior to 1800 and now in the Ethnologisches Museum in Berlin (Germany). A second painted pair of a different shape remains unidentified in the Bristol City Museum (England).

The tikanagan (cradle board) provides a wealth of information. Made in the traditional manner, the wooden frame is presumed to have been shaped and decorated by a man (Figs. 9, 10). Decorated with a scalloped upper edge and a cut-out heart, we can draw comparisons with it to one collected by Alanson Skinner in $1908^{108}$ which bears a similar cut-out. These same features, which occur on a cradle board held by the Manchester Museum (0.8627), suggest that the community of origin for this otherwise unprovenanced tikanagan is also Moose Factory. ${ }^{109}$ The floral beadwork on the laced tikanagan cover, while not as elaborate as that found on full-size examples, does provide evidence of colour choice and motifs. Drawing upon the premise that decorative rosebuds can be considered a Cree woman's "signature,"110 isolation of the beaded rosebuds on this cradle board cover allows comparison with unidentified material to identify the maker, at least at the community level.

107 Cath Oberholtzer, "Cree Leggings: A Sign of Identity," in Papers of the Twenty-fifth Algonquian Conference, ed. William Cowan (Ottawa: Carleton University, 1994), 347-72.

108 American Museum of Natural History 50-6943. See also a photograph of the miniature tikanagan which Ellen Smallboy made for anthropologist Regina Flannery in 1933. Regina Flannery, Ellen Smallboy: Climpses of a Cree Woman's Life (McGill-Queen's University Press, 1995), 6. Elten Smallboy, the central figure in Flannery's book, was at Moose Factory when Malloch was there.

109 Cath Oberholtzer, "Womb With A View": Cree Moss Bags and Cradle Boards," in Papers of the Twenty-eighth Algonquian Conference, ed. David Pentland (Winnipeg: University of Manitoba, 1997), 258-73.

110 Cath Oberholtzer, "A Thorny Identification: Rosebuds as Symbols of Native Identity,"journal of American Studies of Turkey 8 (1998): 13-27 
Of particular interest is the glimpse of the tartan moss bag (Fig. 11) under the lacing. From birth babies were surrounded with moss and then wrapped into moss bags. However, not only is this the only museum example indicating that moss bags were then placed inside tikanagan covers, but also the only evidence we have that tartan (plaid) and floral bead work were used at the same time.

Other comparisons can be extrapolated from these documented Moose Factory pieces: the shirts (catalogued as "tunics") worn by both Alice and Stewart (Figs. 1,3,12) in the studio portraits allow us to provide a provenance for two virtually identical shirts owned and illustrated by a private collector in Montana. ${ }^{111}$ A model canoe (Fig. 13) "made by the Cree Indians" which looks like a cross between an Inuit kayak and a Cree canoe is strikingly similar to a flotilla of unidentified ones in the Leeds Museum in England. As well, the moccasins (10/28a,d; 10/30a,b,c,d) and a "wall pocket" (bag; 10/89) accessioned in 1879 by the American Museum of Natural History in New York City were donated by Robert Bell but otherwise lack any mention of origins. However, comparisons with items in the Malloch collection suggest that Bell likely collected them during visits to Moose Factory when his cousin, William Malloch was there. Alternatively, Malloch may have forwarded the items to Bell. Nonetheless, the quality of the work echoes that of the Malloch pieces, all of which are certainly of a higher standard than one would expect for mere tourist pieces.

Included in the collection is a miniature, or model, canoe paddle (Fig. 14) painted and decorated with a typical meandering line accentuated with a scattering of attached flowers. On one side of the handle the name "Alice" is written in pencil and painted on the blade is "Ness." A note tied to the handle states that: "The design, painted on the paddle, was one taught to the Indians by Bishop John Horden." This is doubtful. When John Horden made a sketch of Hannah Che-ah-pun at Moose Factory in 1852, he depicted her wearing a beaded-cloth hood ornamented with a very similar design. ${ }^{112}$ As the Hordens had only arrived the year before, as the hood in question indicates a familiarity and expertise in tendering the design, and as the usual transmission of sewing techniques was passed on from woman to woman, it does not seem probable that Horden could have introduced the design that quickly.

Although I have compiled lists ${ }^{113}$ of men and women who were at Moose Factory during the eight years that Malloch was engaged as a surgeon and clerk, ${ }^{114}$ there is absolutely no indication in the records assessed which of these people may have made the items. Not only do we not know who made these items, we do not know whether Malloch bought them, commissioned them, received them from grateful patients, or if they were outright gifts. We do know from the articles themselves that each of the Creemade items was made expertly reflecting the pride of artistry, and was intended to show the deep respect which the doctor and his family engendered.

Today this collection forms a material basis for knowledge of the Cree past. These cultural artifacts comprise a record through which native peoples,

111 Douglas Ewing, Pleasing the Spirits: A Catalogue of a Collection of American Indian Art (New York: Ghylen Press, 1982), 189; catalogue numbers $X / 9$ and $X / 10$; plate 173 .

112 For an illustration see Cath Oberholtzer, "Embedded Symbolism: The James Bay Beaded Hoods," Northeast Indian Quarterly 8, no. 2 (1991): 18-27.

113 These lists were compiled from all archival sources assessed, but especially from baptismal records which give the parents' names and the fathers' occupations.

114 After 1821, surgeons were hired to serve as both clerks and doctors; see Payne, The Most Respectable Place, 104. 
scholars, and the public can gain access to this chapter of the native past, and of Canadian history.

Thank you, Dr. Malloch, for that legacy.

\section{APPENDIX I: CONTENTS OF THE COLLECTION}

18536 Sled (model): wood, bone runners, and harness for one dog.

M18537 Kayak (model): skin, wood.

M18538 Cradle board (miniature): wood, paint, cotton, linen, moss, buttons, caribou thongs, silk ribbon, wool broad-cloth, seam binding, beads, thread.

M18559 Moccasins (child's): caribou hide, silk floss, sinew.

M18560 Slipper moccasins (child's): caribou hide, cotton, sinew, silk floss.

M18562 Moccasins (doll's): caribou hide, woollen cloth, silk floss, sinew.

M18563.1-2 Mittens: caribou hide, silk ribbon, sinew, buttons.

M18564 "Tunic" [shirt] (child's): caribou hide, thread, silk floss, silk ribbon, fur, buttons.

M18564.1 Belt (child's): caribou hide, thread, silk floss, fur, buttons.

M18572 Canoe and paddles (model): birch bark, wood.

M18573 Bow drill. Cree.

M18574 Harpoon head: ivory.

M18575 Arrow shaft: wood, steel.

M18576 Arrow shaft: wood, steel.

M18577 Paddle (model): wood, paint. An accompanying note states that the design on the paddle was one taught to the Indians by Bishop John Horden. On one side of the handle is "Alice" written in pencil; painted on same side of blade is "Ness".
M18578.1-27 Case and medical instruments Case is marked "G. Tiemann \& Co, 63 Chatham St., New York".

M18579 Pipe, button hole type: Used by Dr. W.B. Malloch.

M18580 Epaulettes: caribou hide, silk floss.

ME935.6 Bible cover: caribou hide, silk lining, silk floss, thread.

M18582 Harpoon (model): wood, ivory, hide.

M18584 Piece of walrus ivory.

M18585 Ivory object.

M18586 Needle case: ivory.

M18587 Needle case: ivory.

M18588 Ajaqaq (game): ivory; polar bear shape.

M18589 Needle case: ivory.

M18589.2 Needle case: ivory, bone. One side drilled to form out-line of whale.

M18590 Pendants, part of necklace: ivory.

M18591 Miniature: "Knife"; ivory; suspension hole, part of necklace.

M18592 Miniature: "Knife"; Ivory; suspension hole, part of necklace.

M18593 Ornament: ivory.

M18594 Miniature: "Knife"; ivory, part of necklace.

M18595 Necklace: ivory. (Composed of various miniature items including M18590, M18591, M18592, M18594).

M18596 Ornament: ivory; suspension hole.

M18597 Toggle: ivory

M18598 Toggle: ivory.

M18599 Spoon (model): wood.

M18600 Toggle: ivory.

M18601. Figure: wood; crudely carved.

M18602 Gun pins: metal; two nipple pins for gun.

M18603 Moccasins (child's): caribou hide, wool cloth, sinew, silk floss. 


\section{APPENDIX II: ARCHIVAL MATERIAI.}

M18604 manuscript (title: "Six llundred Miles on Snowshoes") wriften by Dr. William Bell Malloch, appointed by the FBC, as doctor at their establishment at Moose Factory, in 1870. This is an account of Dr. Malloch's journey in winter from Montrcal, to his post in the North West in that year, and includes a description of Moose Island. Comprising 1 typewritten pages.

PHA0254 Almanac.

App W 49/36 New Testament.

RB1440 Catechism: Watt's first, in Eskirno. Printed by F. Annold, 86 Fleet St. F.C.

App M 51/36 Prayer Book.

App M 52/36 Hymn Book: Bishop John Forden's. 1864.

App M 53/36 Book: Icctures on Khetoric, circa 1860.

App M 54/36 Book: Nautical Almanac, 1772.

MP-0000.39 I Jhotographs (33): Life and surroundings in North-West. $1-33$ and near

Moose Factory.

MP-0000.391 Photograph of Dr. Winlian Bell Malloch ca. 1865. 34 .

Ml'-0000.391 Photograph of Stewart linest valloch. 1878. 35 .

MP-0000.391 Photograph of Alice Muricl Malloch 1878.36

App M 64/36 MS notes on photographs in Dr. Malloch's collection.

M936.15.1,1-5 Cigar Case: 1878; containing 4 of the original cigars.
I-42589.1 Photograph of Dr. William Bell

Malloch. 1872 .

[-7351.5.1 Photograph of Mrs. William Be]

Malloch. 1872.

[-7.3516.] Photograph of Dr. and Mrs. William Bell Malloch. 1872.

[-73517.] Photograph of Dr. and Mrs. William Bell Malloch. 1872.

[-73518.1 Pliotograph of Dr. William Bell Malloch posed with snowshoes.

[-73519.1 Photograph of Dr. William Be]l Malloch posed wearing snow shoes.

\section{ACKNOWI,EDGEMENTS}

The financial suptrot provided by the Social Sciences and Humanitics Research Council for this resedrch is gratefully acknowledged. And, as with any research there is always a debt of gratitude accrued which must be noted. In particular I would like to thank Judith Beattie of ihe lludson's Bay Company Archives, Bil Russell of the Rational Archives of Canada, Guislaine Lemay of the McCord Museum, Dr. Toby Moranty. Dr. John S. Tong, David Crawford, and 1)t. A.E. Malloch of the Osler Library at McGili University. While it was through the encouragement of the McCord's Morra McCaffrey, Director, Rescarch and Exhibitions, that this article reached fruition, I take full responsibility for any errors, omissions, or any unintentional misconstruing of facts. Thanks go as well to John Hobbins and David McKuight, the capable actingeditors who trok over the reins for this volume. 


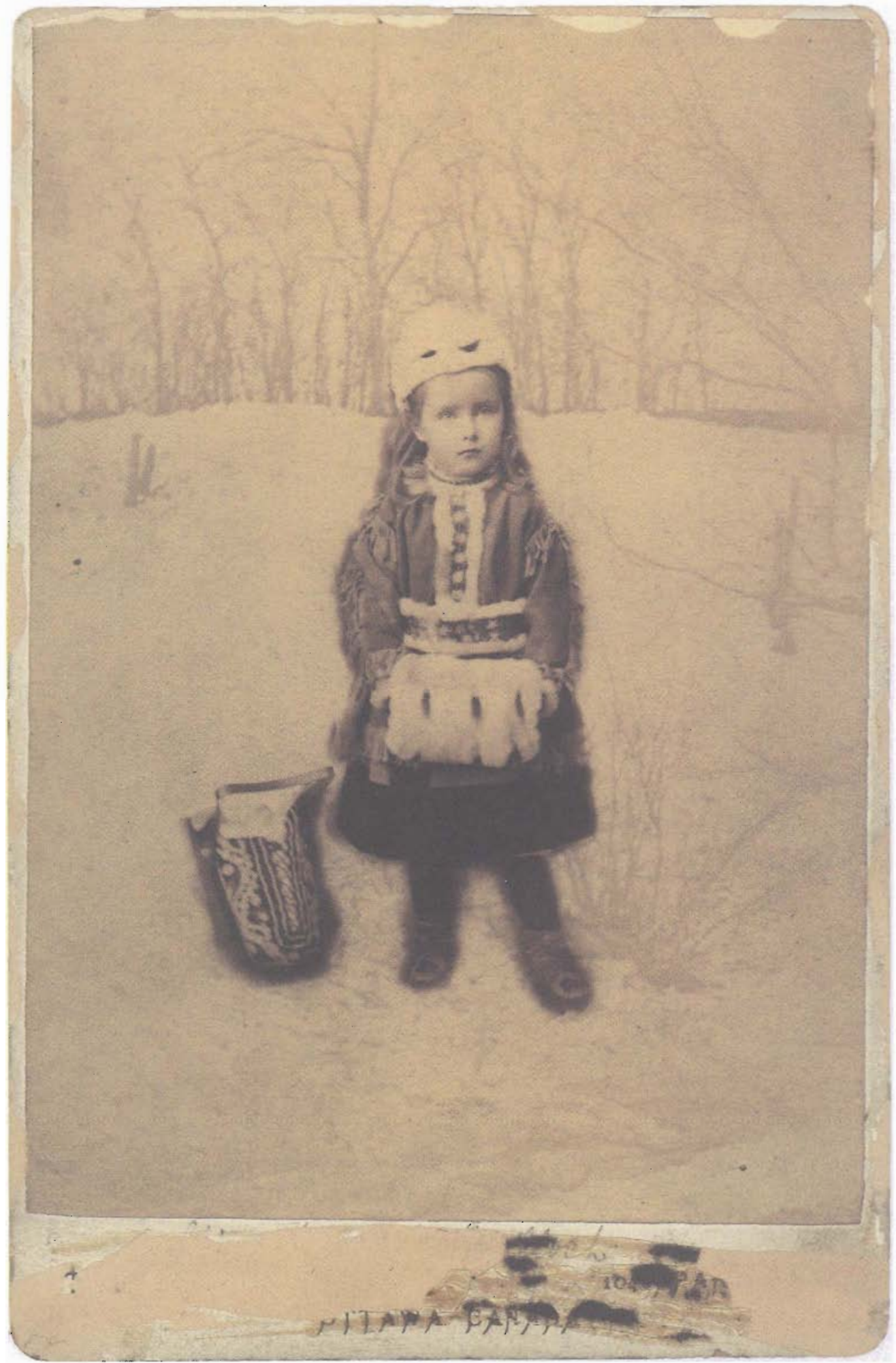

Figure 1. Photograph of Alice Muriel Malloch, 1878. (McCord Museum, William Bell Malloch Collection, M-000.391). 


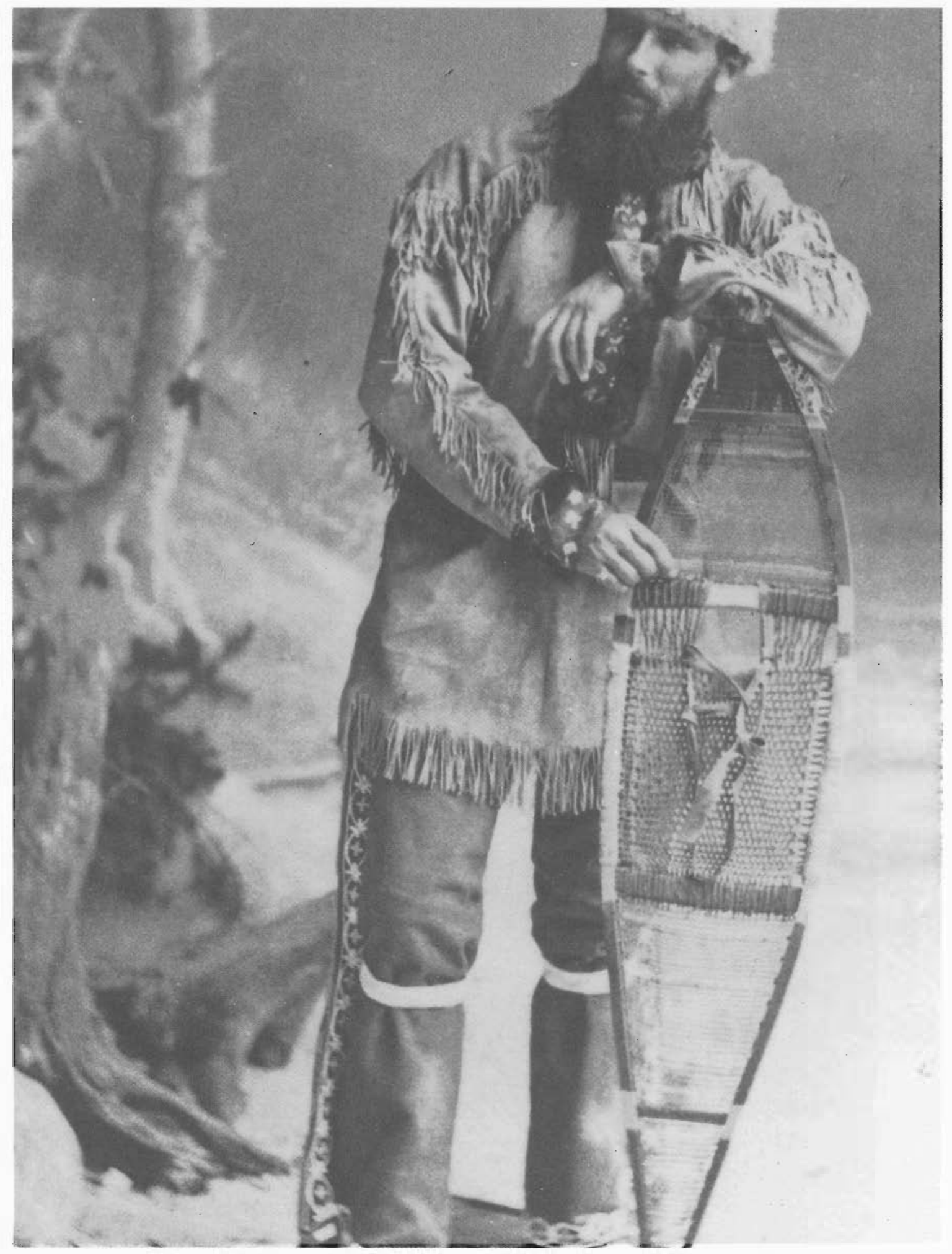

Figure 2. Photograph of Dr. William Bell Malloch posed with snowshoes. (McCord Museum, William Bell Malloch Collection, I-73518.1). 


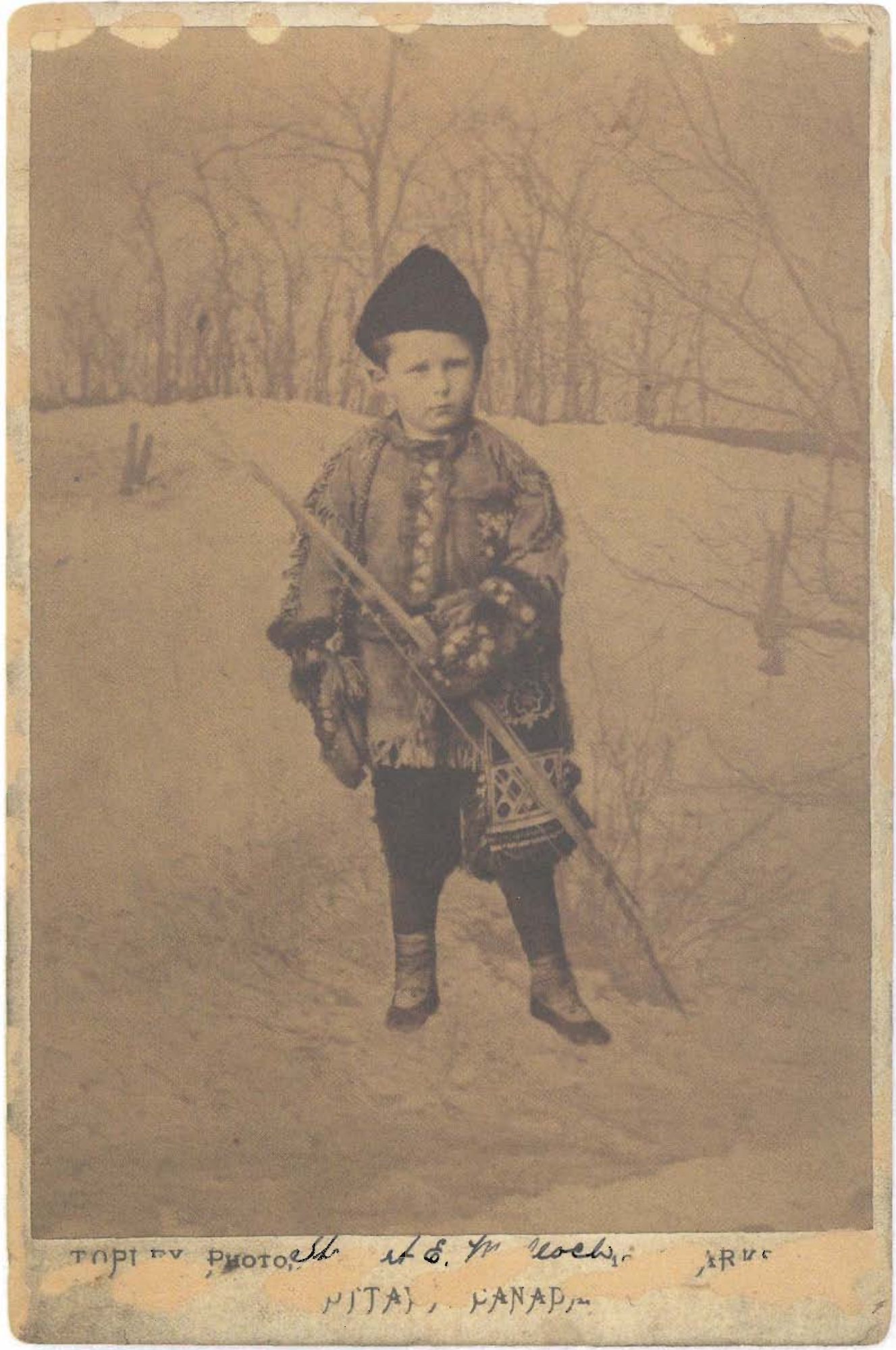

Figure 3. Photograph of Stewart Ernest Malloch, 1878.

(McCord Museum, William Bell Malloch Collection, MP-0000.391). 


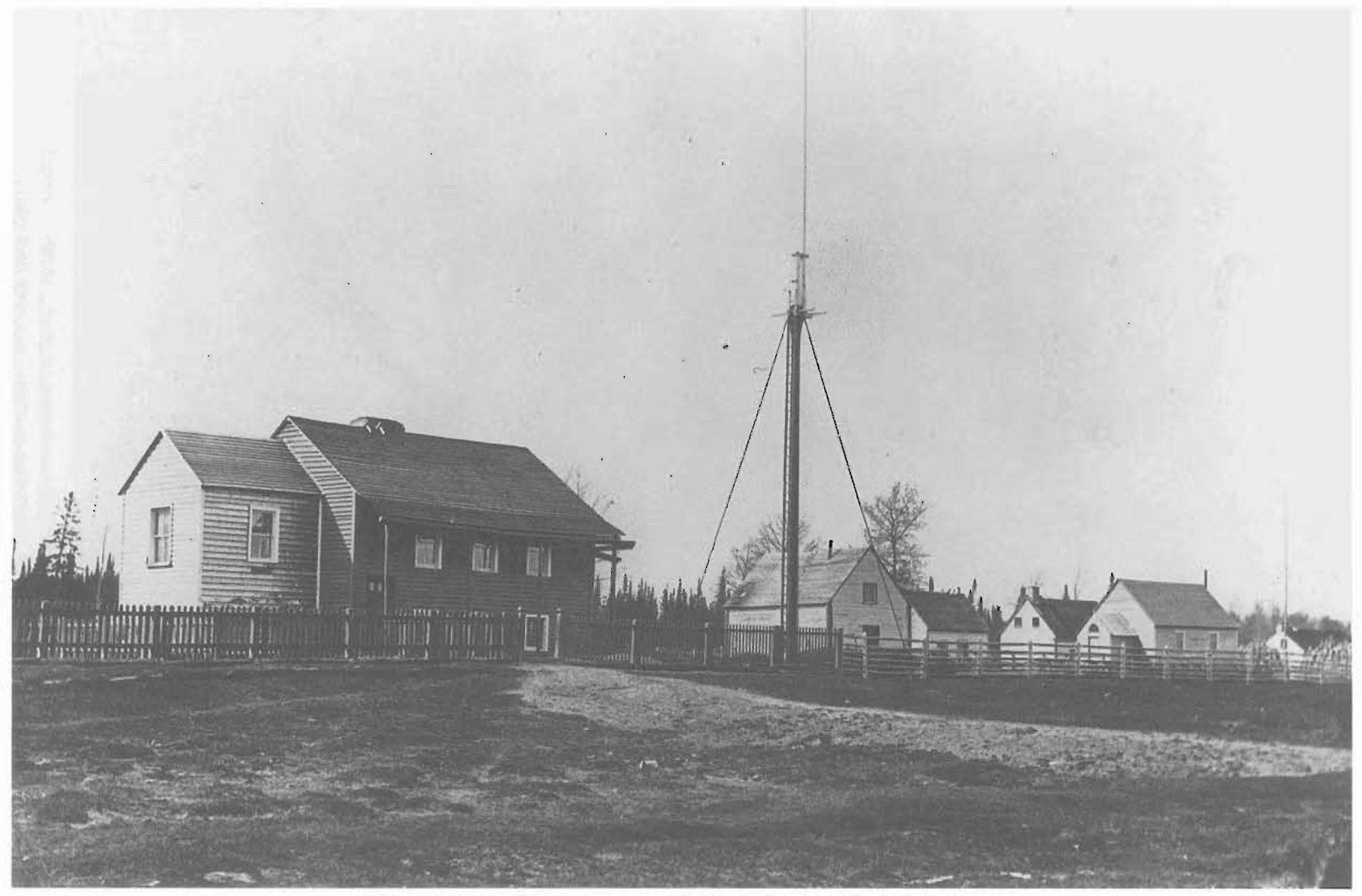

Figure 4. Life and surroundings in North-West and near Moose Factory. (McCord Museum, William Bell Malloch Collection, MP-0000.391.1-33). 


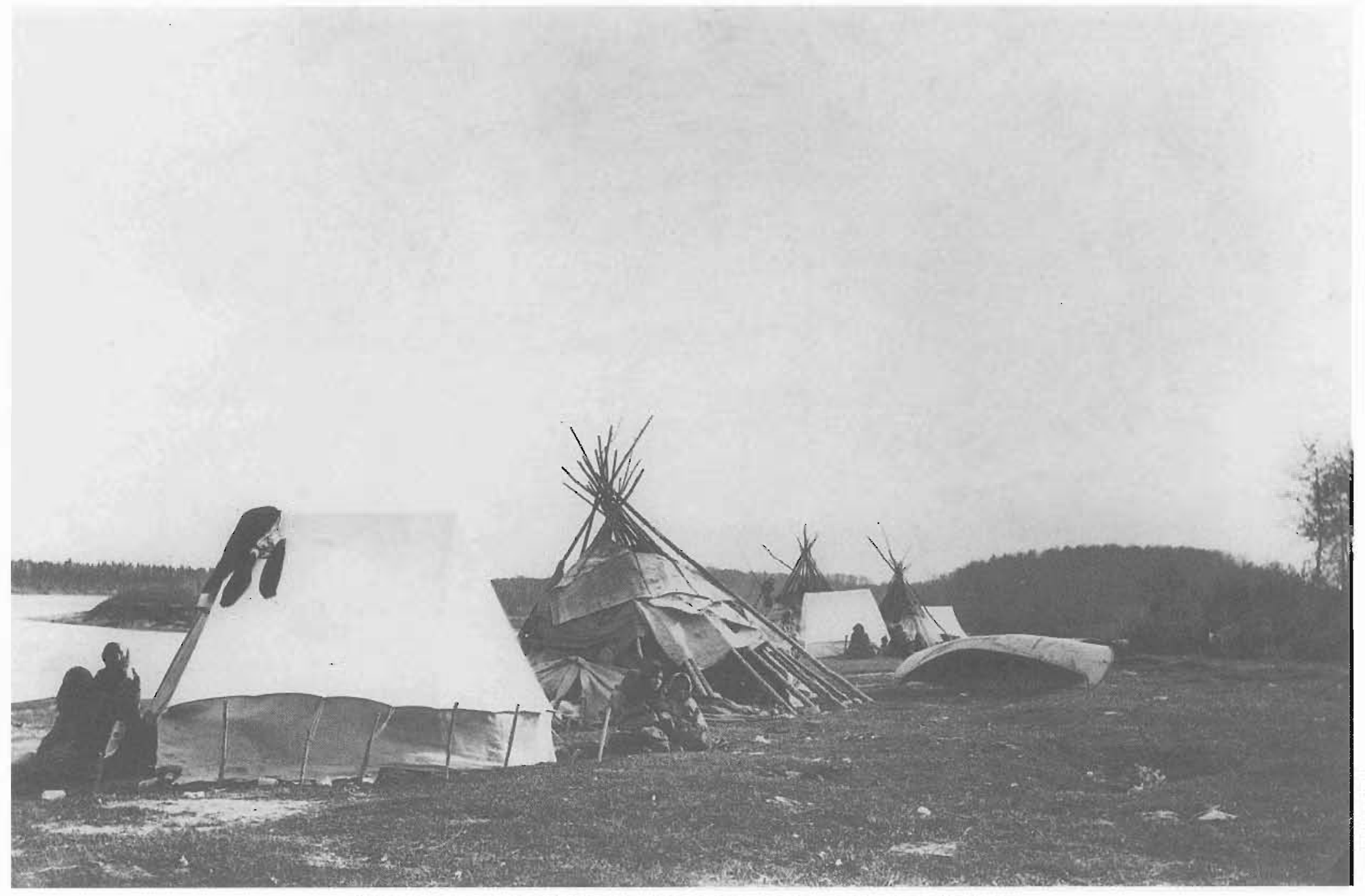

Figure 5. Life and surroundings in North-West and near Moose Factory. (McCord Museum, William Bell Malloch Collection, MP-0000.391.1-33). 


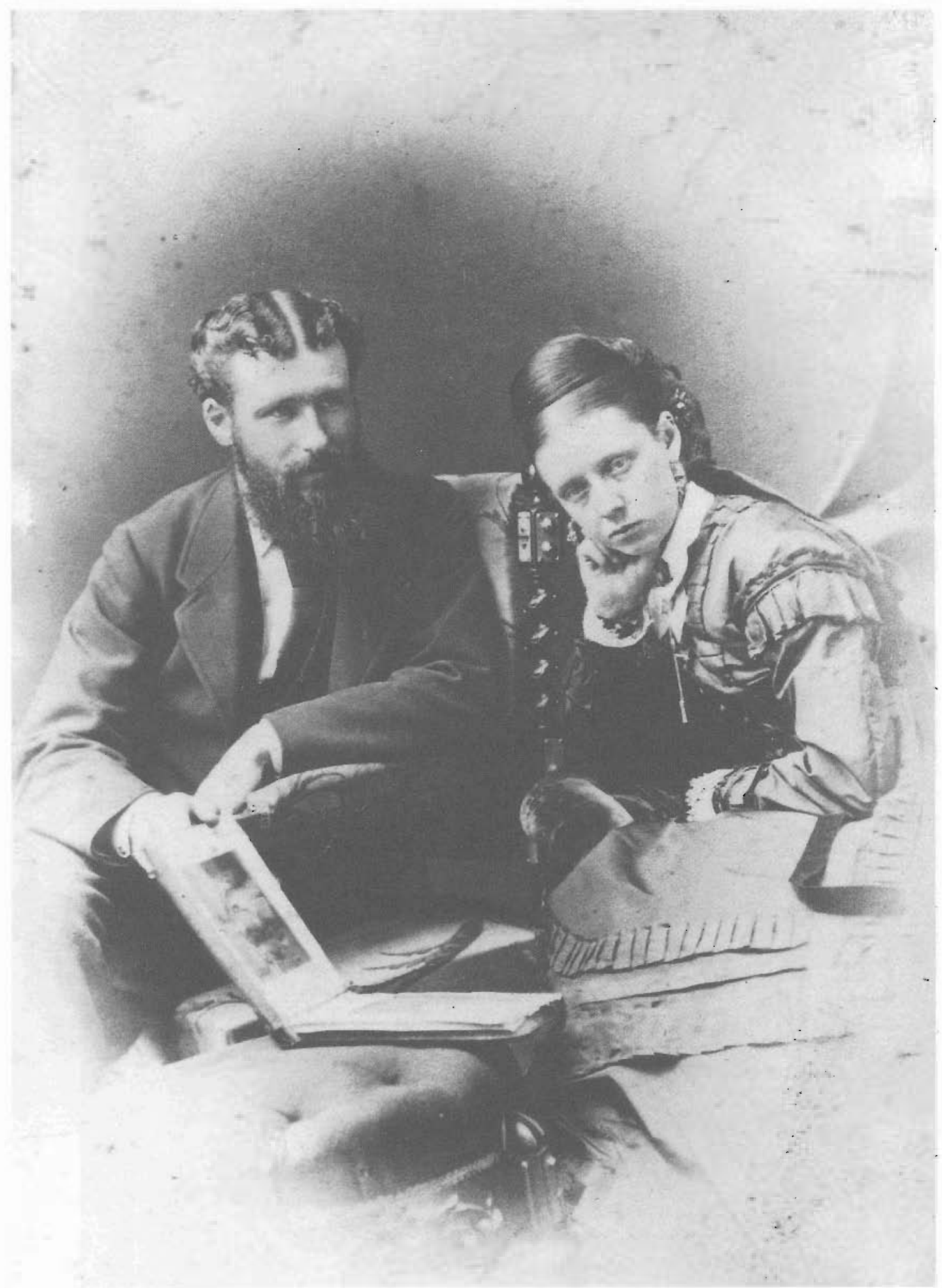

Figure 6. Photograph of Dr. and Mrs. William Bell Malloch, 1872.

(McCord Museum, William Bell Malloch Collection, I-73516.1). 


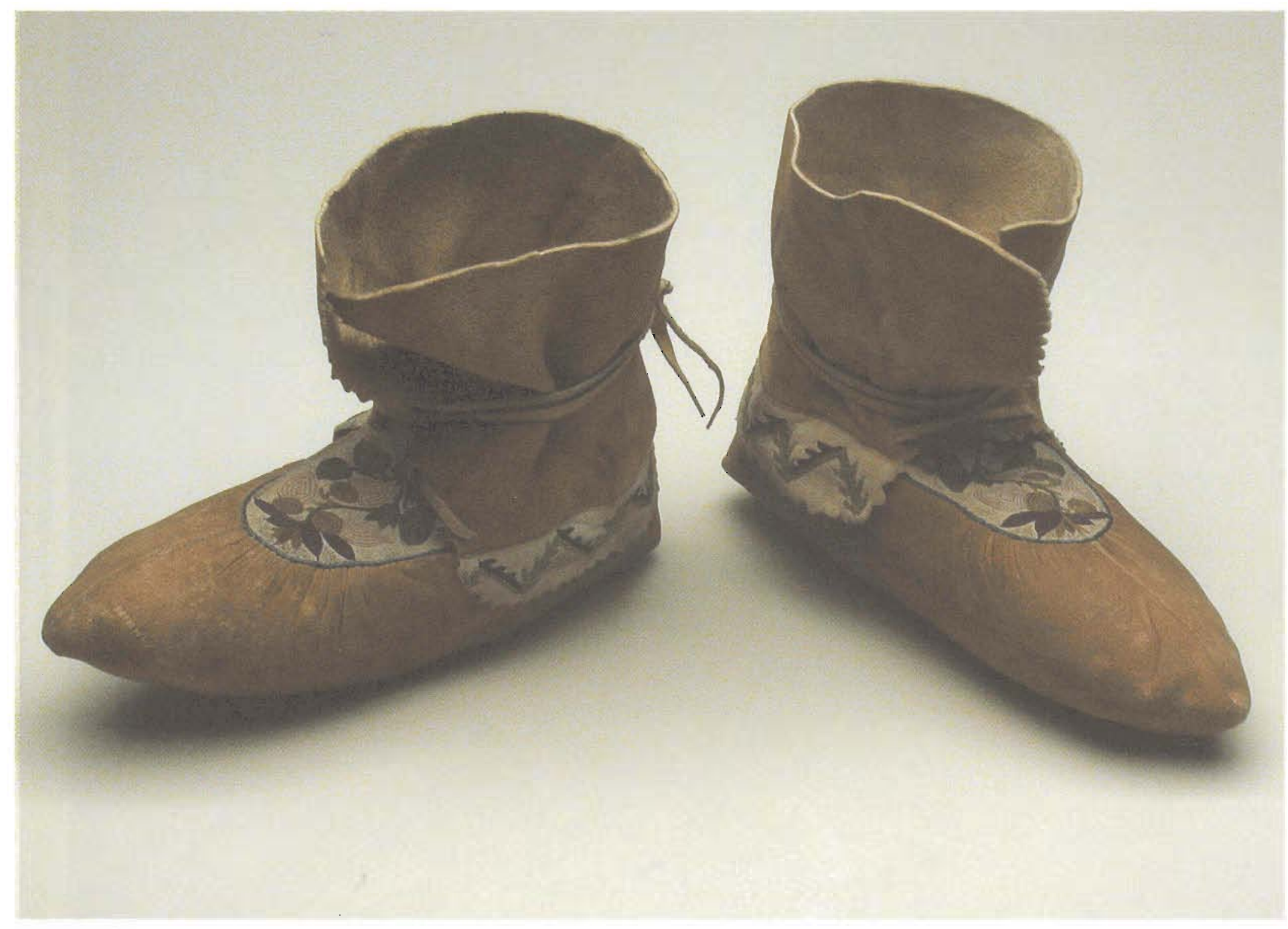




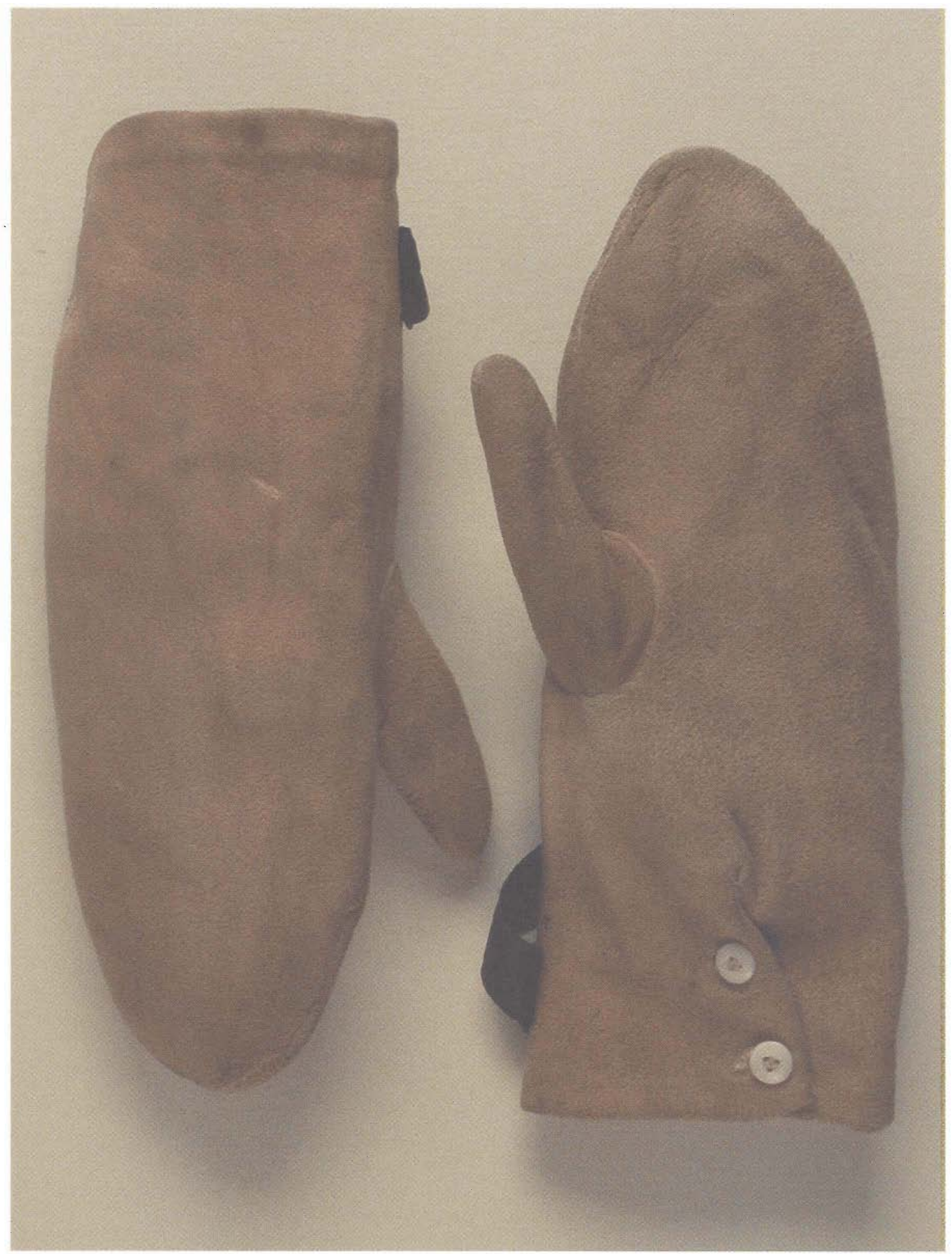

Figure 8. Mittens.

(McCord Museum, William Bell Malloch Collection, M-18563.1-2). 


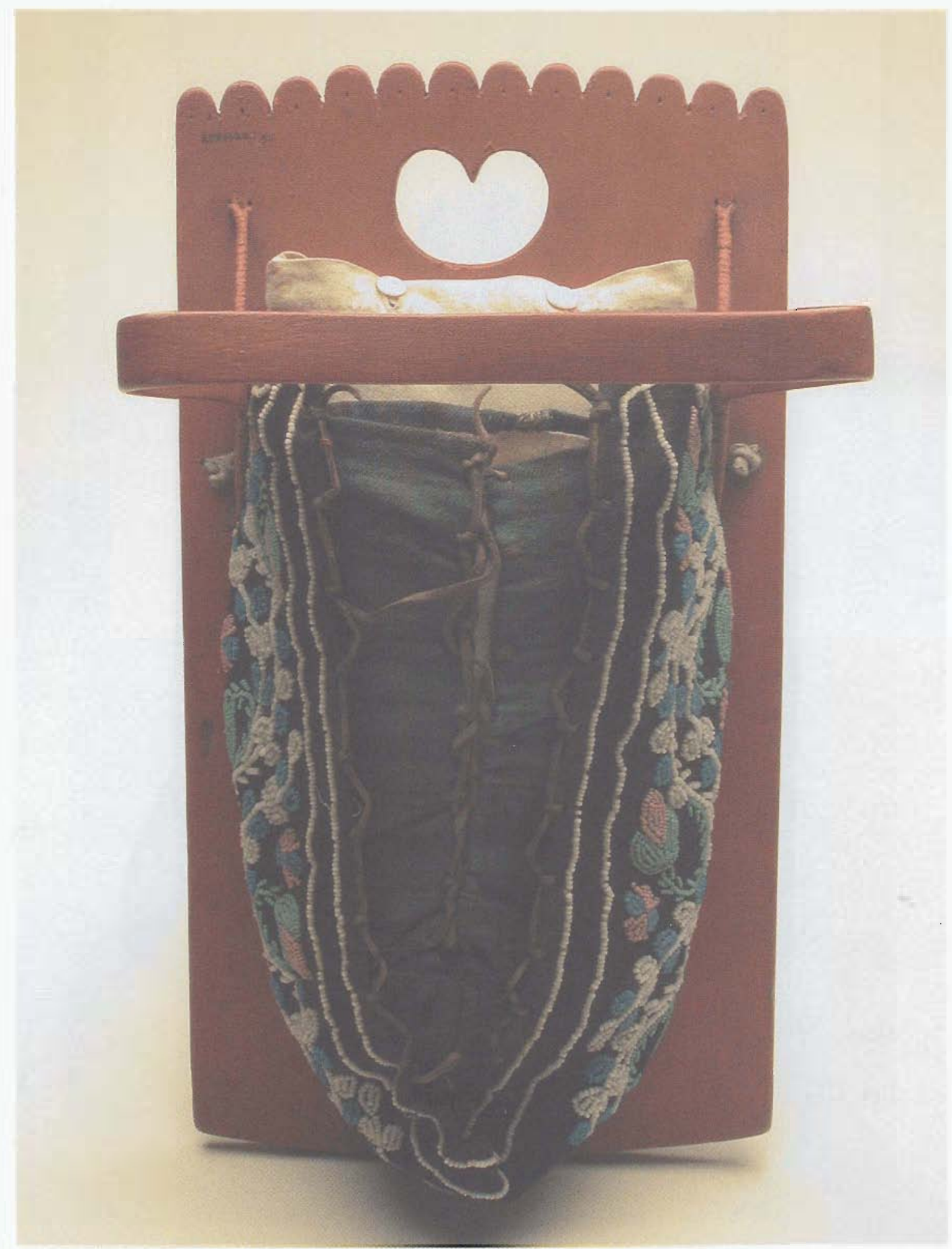

Figure 9. Cradle board (tikanagan) front.

(McCord Museum, William Bell Malloch Collection, M-18538). 


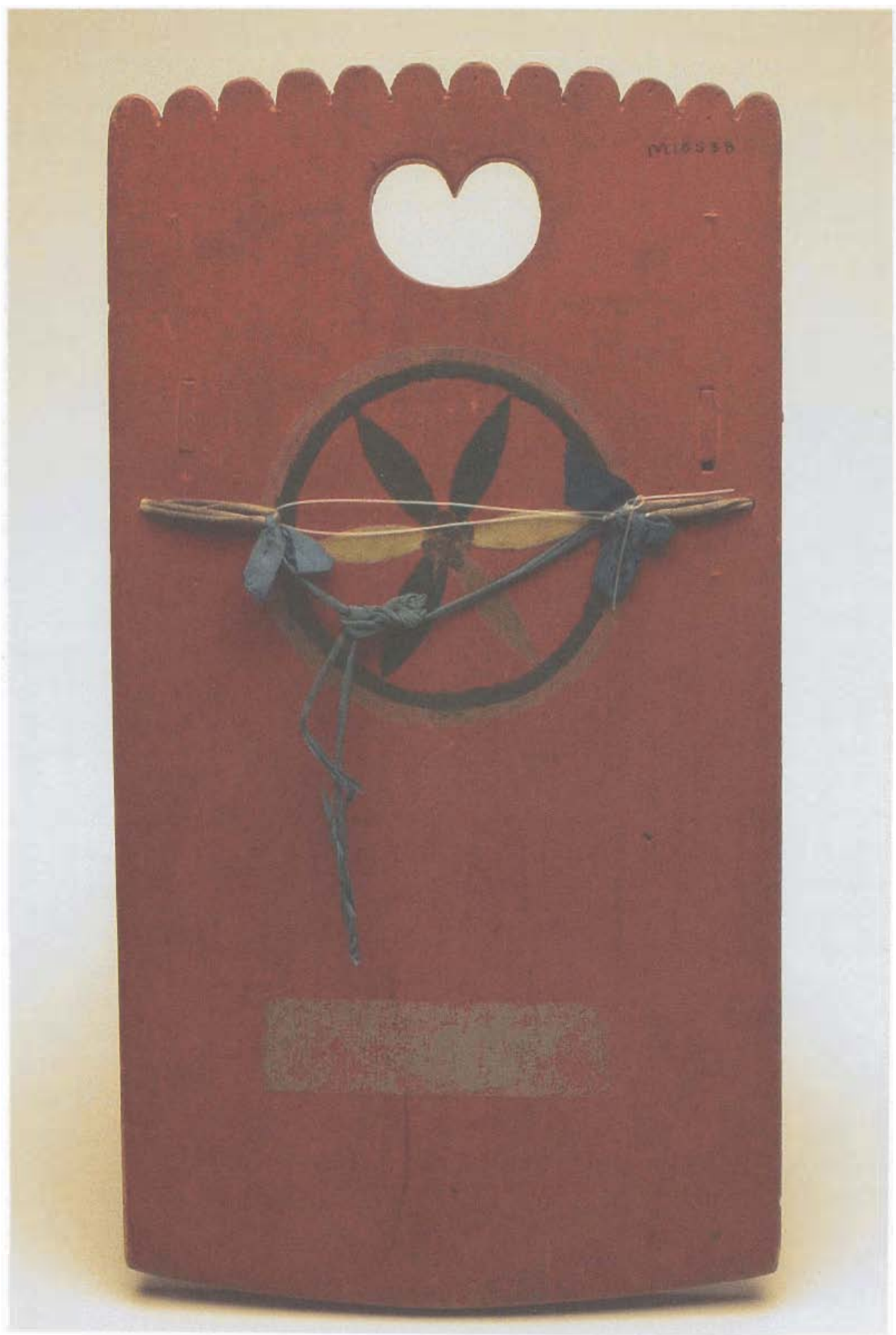

Figure 10. Cradle board (tikanagan) back. (McCord Museum, William Bell Malloch Collection, M-18538). 


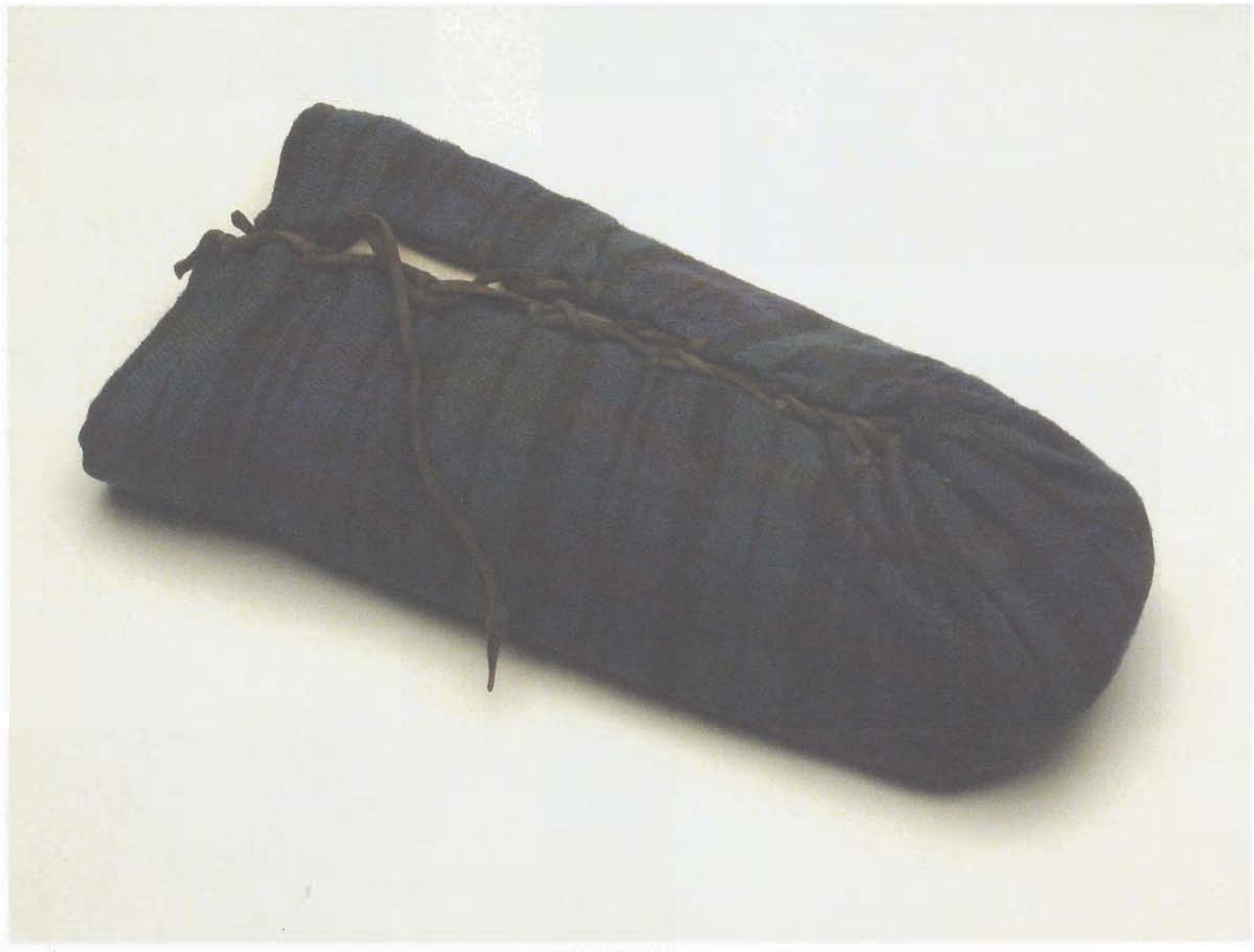




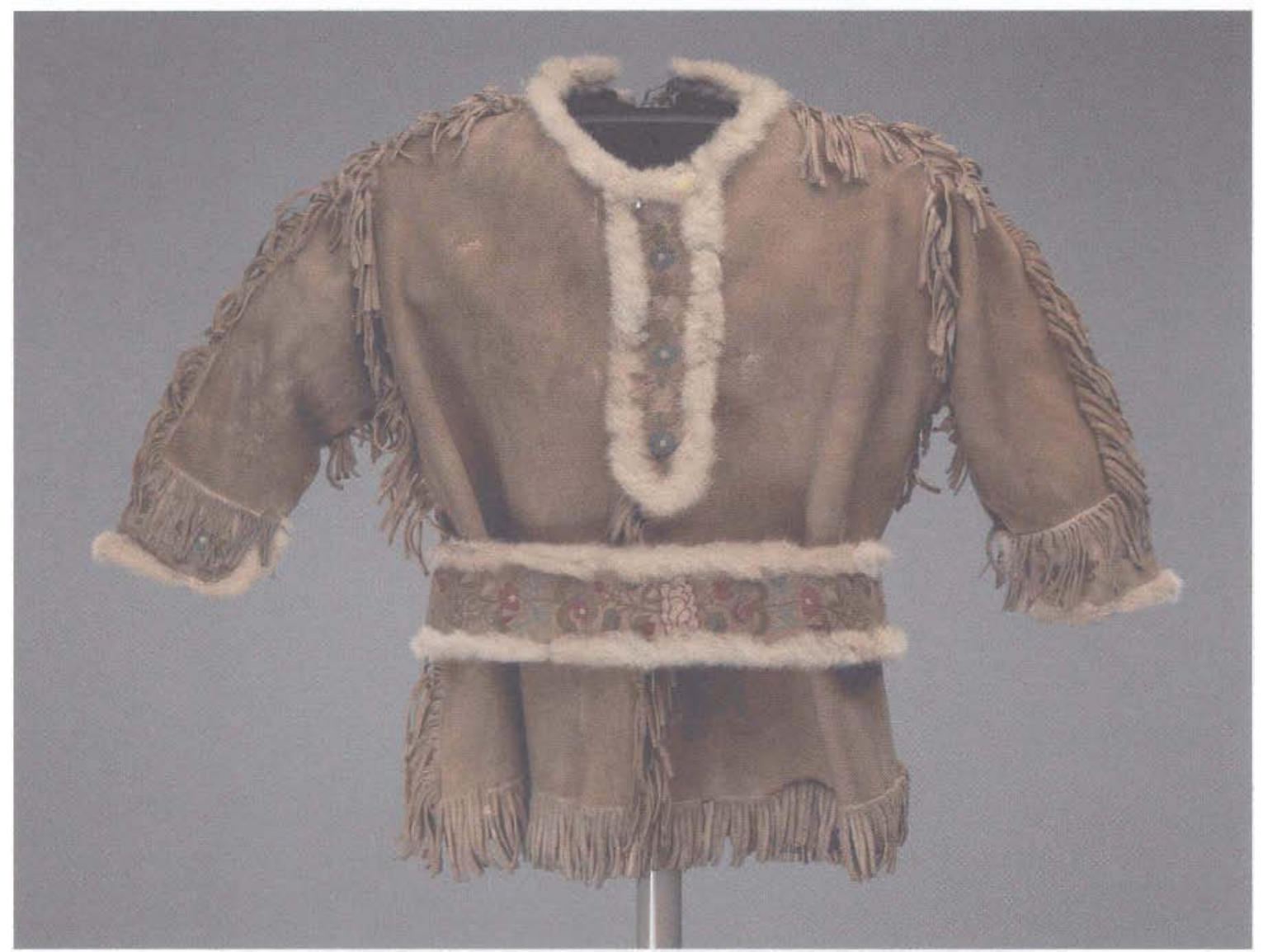

Figure 12. "Tunic" [shirt] (child's) and belt (child's).

(McCord Museum, William Bell Malloch Collection, M-18564).

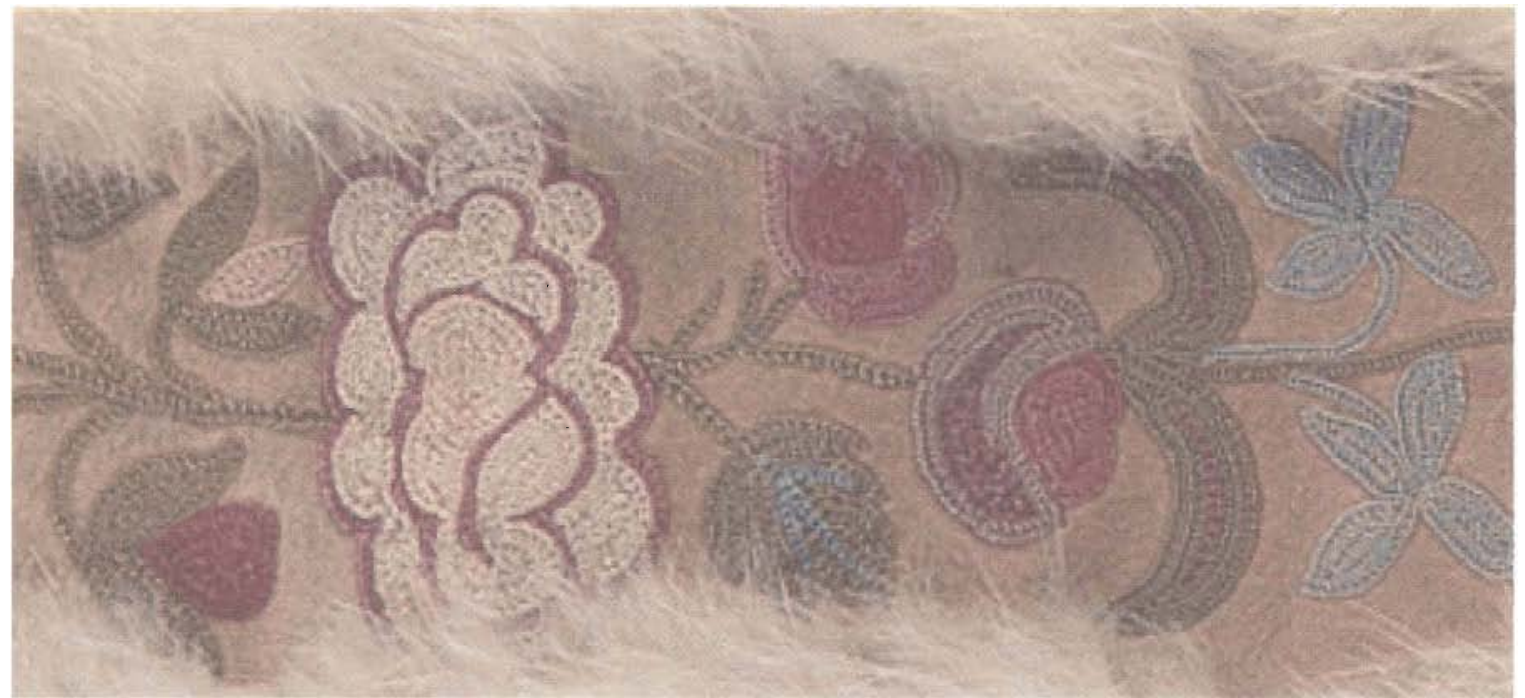

Figure 12a. Detail of a child's belt.

(McCord Museum, William Bell Malloch Collection, M18564.1). 


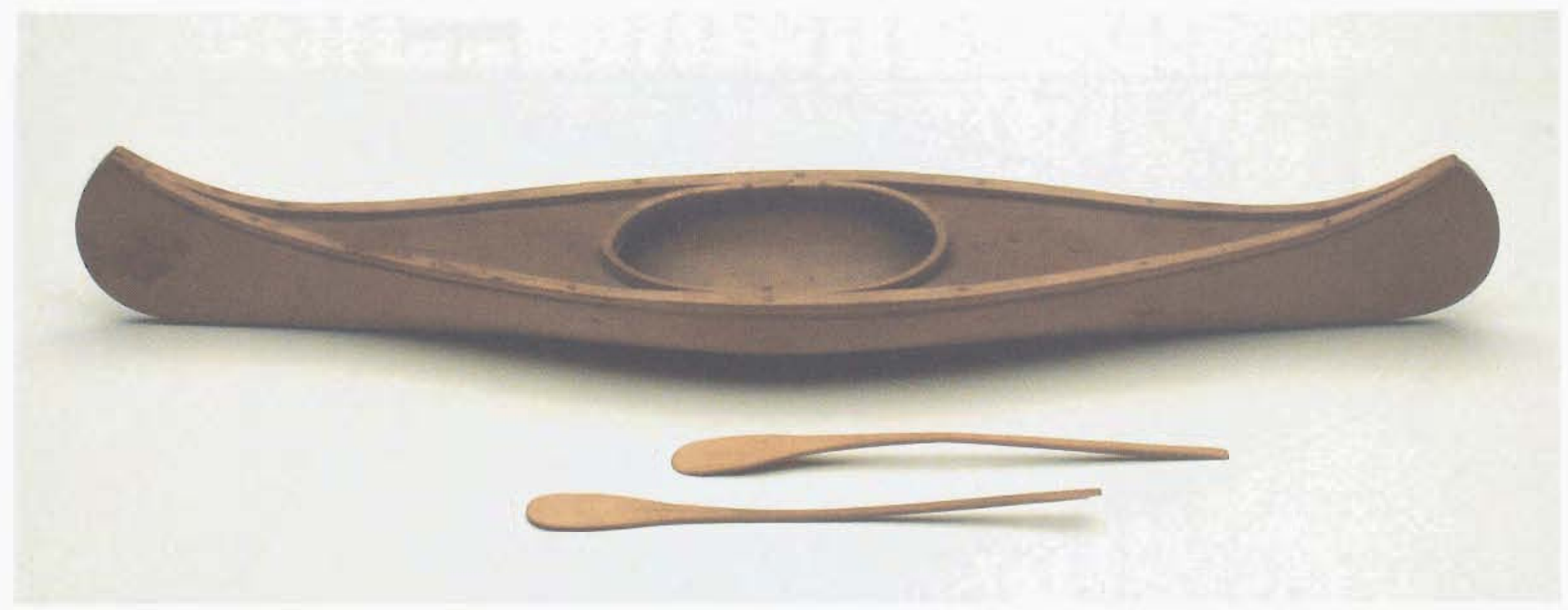

Figure 13. Canoe and paddles (model).

(McCord Museum, William Bell Malloch Collection, M-18572).

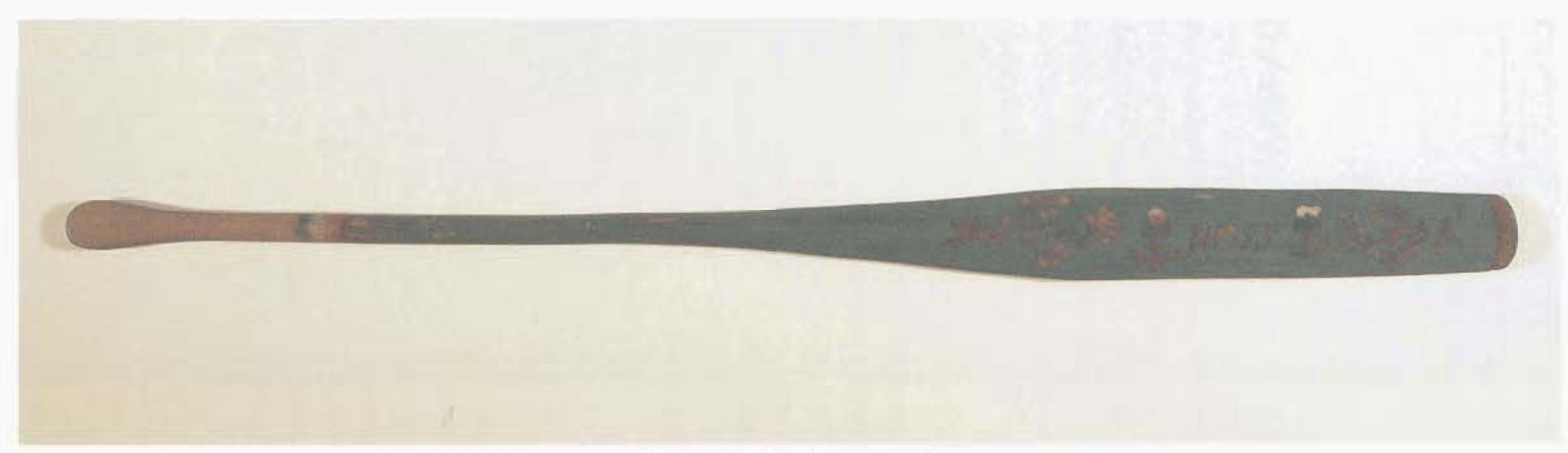

Figure 14. Paddle (modeI).

(McCord Museum, William Bell Malloch Collection, M-18577). 